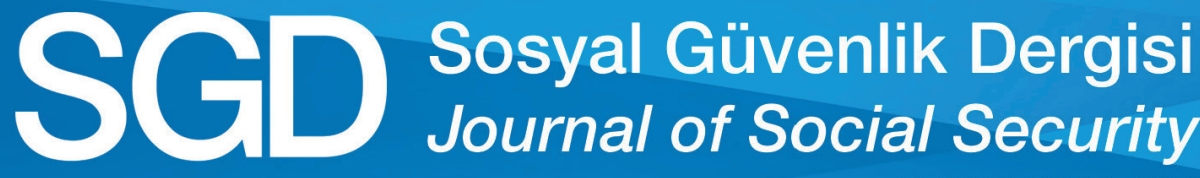

P-ISSN: 2146-4839

E-ISSN: 2148-483X

\section{Çalışanların 6331 Sayılı Kanundan Doğan Yükümlülükleri ve Yükümlülükleri İhlalin Sonuçları}

\section{Employees' Obligations due to Law No 6331 and the Results of Behavior Against Obligations}

\author{
Kübra DEMIR \\ Sivas Cumhuriyet Üniversitesi, Hukuk Fakültesi
}

Aralık 2020, Cilt 10, Say1 2, Sayfa 393-412

December 2020, Volume 10, Issue 2, Page

393-412

P-ISSN: $2146-4839$

E-ISSN: 2148-483X

$2020-2$

e-posta:sgd@sgk.gov.tr

Yazılar yayınlanmak üzere kabul edildiği takdirde, SGD elektronik ortamda tam metin olarak yayımlamak da dahil olmak üzere, tüm yayın haklarına sahip olacaktır. Yayınlanan yazılardaki görüşlerin sorumluluğu yazarına aittir. Yazı ve tablolardan kaynak gösterilerek alıntı yapılabilir.

If the manuscripts are accepted to be published, the SGD has the possession of right of publicationand the copyright of the manuscripts, included publishing the whole text in the digital area. Articles published in the journal represent solely the views of the authors.

Some parts of the articles and the tables can be citeded by showing the source. 


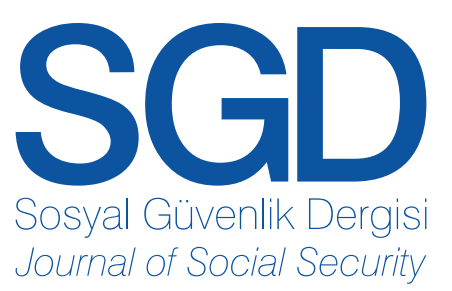

Cilt: 10 - Say1: 2 - Y11: 2020

Volume: 10 - Issue: 2 - Year: 2020

P-ISSN: 2146-4839

E-ISSN: 2148-483X

Sahibi / Owner of the Journal

Sosyal Güvenlik Kurumu Adına / On behalf of the Social Security Institution

İsmail YILMAZ

(Kurum Başkanı / President of the Institution)

Sorumlu Yazı İşleri Müdürü / Responsible Publication Manager

Uğur KORKMAZ



Editörler / Editors

Doç. Dr. Erdem CAM

Selda DEMİR

Redaksiyon / Redaction

Nihan ERTÜRK

Yayın Türü: Uluslararası Süreli Yayın / Type of Publication: International Periodical

Yayın Aralığı: 6 aylık / Frequency of Publication: Twice a Year

Dili: Türkçe ve İngilizce / Language: Turkish and English

Basım Tarihi / Press Date: 20.12.2020

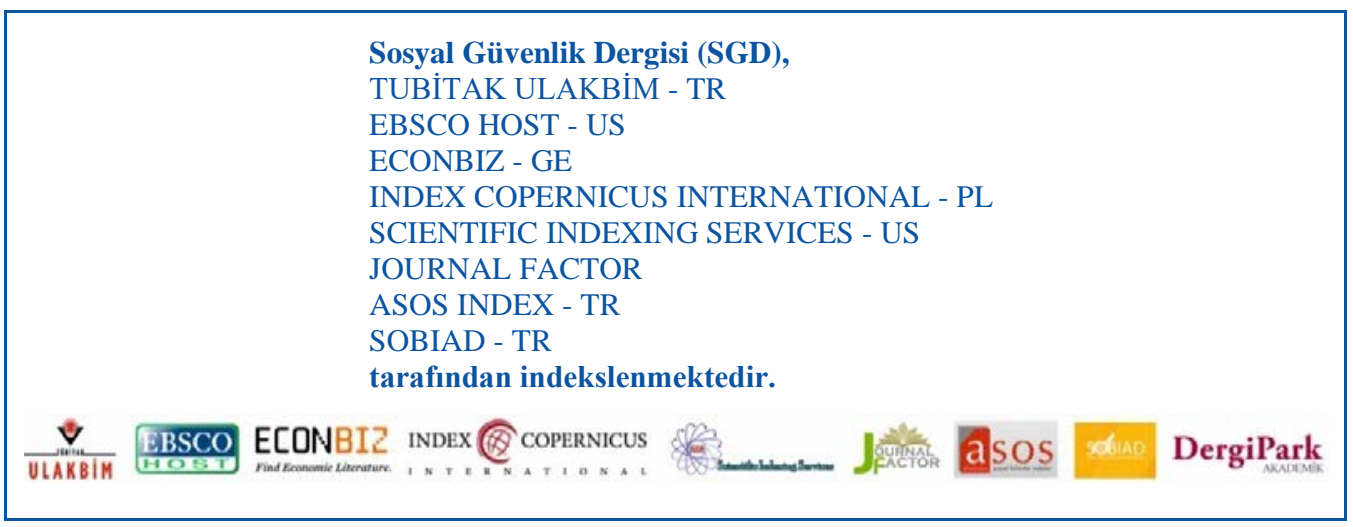

CTüm hakları saklıdır. Sosyal Güvenlik Dergisi’nde yer alan bilimsel çalışmaların bir kısmı ya da tamamı telif hakları saklı kalmak üzere eğitim, araştırma ve bilimsel amaçlarla çoğaltılabilir. Dergide yayımlanan makalelerdeki fikir ve görüşler Sosyal Güvenlik Kurumunun kurumsal görüşünü yansıtmaz, tüm görüşler yazarlarına aittir.

Tasarım / Design: PERSPEKTİF Matbaacılık Tasarım Tic.Ltd.Şti. (0 312) 3842055 - Ankara

Basım Yeri / Printed in: PERSPEKTİF Matbaacılık Tasarım Tic.Ltd.Şti. (0 312) 3842055 - Ankara

İletişim Bilgileri / Contact Information

Sosyal Güvenlik Kurumu Başkanlığı

Ziyabey Caddesi No: 6 Balgat / Ankara / TÜRKIYE

Tel / Phone: +90 3122078891 - 2078770 - Faks / Fax: +90 3122077819

Erişim/Webpage: http://www.sgk.gov.tr/wps/portal/sgk/sgd/tr - e-posta / e-mail: sgd@sgk.gov.tr 
Professor Yener ALTUNBAȘ

Bangor University - UK

Professor Paul Leonard GALLINA

Bishop’s University - CA

Professor Jacqueline S.ISMAEL

University of Calgary - CA
Professor Özay MEHMET

University of Carleton - CA

Professor Allan MOSCOVITCH

University of Carleton - CA

Professor Mark THOMPSON

University of British Columbia - CA
Asst. Prof. Sara HSU

State University of New York- USA

Asst. Prof. C. Rada Von ARNIM

University of Utah - USA

\section{ULUSAL DANIŞMA KURULU / NATIONAL ADVISORY BOARD}

Prof. Dr. Ahmet Cevat ACAR

İstanbul Üniversitesi

İşletme Fakültesi

Prof. Dr. İsmail AĞIRBAŞ

Ankara Üniversitesi

Sağlık Bilimleri Fakültesi

Prof. Dr. Levent AKIN

Ankara Üniversitesi

Hukuk Fakültesi

Prof. Dr. Yusuf ALPER

Bursa Uludağ Üniversitesi

İktisadi ve İdari Bilimler Fakültesi

Prof. Dr. Faruk ANDAÇ

Cağ Üniversitesi

Hukuk Fakültesi

Prof. Dr. Kadir ARICI

Ankara Hacı Bayram Veli Üniversitesi

Hukuk Fakültesi

Prof. Dr. Onur Ender ASLAN

Ankara Sosyal Bilimler Üniversitesi

Siyasal Bilgiler Fakültesi

Prof. Dr. Zakir AVŞAR

Ankara Hacı Bayram Veli Üniversitesi

İletișim Fakültesi

Prof. Dr. Ufuk AYDIN

İstanbul Aydın Üniversitesi

Hukuk Fakültesi

Prof. Dr. Abdurrahman AYHAN

Kıbris İlim Üniversitesi

Hukuk Fakültesi

Prof. Dr. Serpil AYTAÇ

Bursa Uludağ Üniversitesi

İktisadi ve İdari Bilimler Fakültesi

Prof. Dr. Mehmet BARCA

Ankara Sosyal Bilimler Üniversitesi

Siyasal Bilgiler Fakültesi

Prof. Dr. Süleyman BAŞTERZI

Ankara Üniversitesi

Hukuk Fakültesi

Prof. Dr. Nursen CANIKLİOĞLU

Marmara Üniversitesi

Hukuk Fakültesi

Prof. Dr. Fevzi DEMIR

Yaşar Üniversitesi

Hukuk Fakültesi
Prof. Dr. A. Murat DEMIRCİOĞLU

Yıldız Teknik Üniversitesi

Emekli Öğretim Üyesi

Prof. Dr. Ömer EKMEKÇI

İstanbul Üniversitesi

Hukuk Fakültesi

Prof. Dr. E. Murat ENGIN

Galatasaray Üniversitesi

Hukuk Fakültesi

Prof. Dr. Hediye ERGİN

Marmara Üniversitesi

İktisat Fakültesi

Prof. Dr. Şükran ERTÜRK

Dokuz Eylül Üniversitesi

Hukuk Fakültesi

Prof. Dr. Afsun Ezel ESATOĞLU

Ankara Üniversitesi

Sağlık Bilimleri Fakültesi

Prof. Dr. Ali GÜZEL

Kadir Has Üniversitesi

Hukuk Fakültesi

Prof. Dr. Alpay HEKIMLER

Tekirdağ Namık Kemal Üniversitesi

İktisadi ve İdari Bilimler Fakültesi

Prof. Dr. Oğuz KARADENIZ

Pamukkale Üniversitesi

İktisadi ve İdari Bilimler Fakültesi

Prof. Dr. Aşkın KESER

Bursa Uludağ Üniversitesi

İktisadi ve İdari Bilimler Fakültesi

Prof. Dr. Cem KILIC

TOBB Ekonomi ve Teknoloji Üniversitesi

İktisadi ve İdari Bilimler Fakültesi

Prof. Dr. Ali Riza OKUR

İstanbul Sabahattin Zaim Üniversitesi

Hukuk Fakültesi

Prof. Dr. Serdar SAYAN

TOBB Ekonomi ve Teknoloji Üniversitesi

İktisadi ve İdari Bilimler Fakültesi

Prof. Dr. Ali Nazım SÖZER

Yaşar Üniversitesi

Hukuk Fakültesi

Prof. Dr. Sarper SÜZEK

Atılım Üniversitesi

Hukuk Fakültesi
Prof. Dr. Müjdat SAKAR

Marmara Üniversitesi

İktisat Fakültesi

Prof. Dr. Savas TASKENT

İstanbul Teknik Üniversitesi

İşletme Fakültesi

Prof. Dr. Ferda YERDELEN TATOĞLU

İstanbul Üniversitesi

İktisat Fakültesi

Prof. Dr. Sabri TEKİR

İzmir Demokrasi Üniversitesi

İktisadi ve İdari Bilimler Fakültesi

Prof. Dr. Mehmet TOP

Hacettepe Üniversitesi

İktisadi ve İdari Bilimler Fakültesi

Prof. Dr. Türker TOPALHAN

Ankara Hacı Bayram Veli Üniversitesi

İktisadi ve İdari Bilimler Fakültesi

Prof. Dr. Aziz Can TUNCAY

Bahçeşehir Üniversitesi

Hukuk Fakültesi

Prof. Dr. M. Fatih USAN

Ankara Yıldırım Beyazıt Üniversitesi

Hukuk Fakültesi

Prof. Dr. Gülbiye YENIMAHALLELI

Ankara Üniversitesi

Sağlık Bilimleri Fakültesi

Doç. Dr. Gaye BAYCIK

Ankara Üniversitesi

Hukuk Fakültesi

Doc. Dr. Emel İSLAMOĞLU

Sakarya Üniversitesi

Siyasal Bilgiler Fakültesi

Doç. Dr. Saim OCAK

Marmara Üniversitesi

Hukuk Fakültesi

Doç. Dr. Ercüment ÖZKARACA

Marmara Üniversitesi

Hukuk Fakültesi

Doç. Dr. Sinem YILDIRIMALP

Sakarya Üniversitesi

Siyasal Bilgiler Fakültesi 
Prof. Dr. Levent AKIN

Ankara Üniversitesi

Hukuk Fakültesi

Prof. Dr. Yusuf ALPER

Bursa Uludağ Üniversitesi

İktisadi ve İdari Bilimler Fakültesi

Prof. Dr. Murat ATAN

Ankara Hacı Bayram Veli Üniversitesi

İktisadi ve İdari Bilimler Fakültesi

Prof. Dr. Sibel ATAN

Ankara Hacı Bayram Veli Üniversitesi

İktisadi ve İdari Bilimler Fakültesi

Prof. Dr. Şenay ÜÇDOĞRUK BİRECIKLII

Dokuz Eylül Üniversitesi

İktisadi ve İdari Bilimler Fakültesi

Prof. Dr. Nurşen CANIKLİĞGLU

Marmara Üniversitesi

Hukuk Fakültesi

Prof. Dr. Elif GÖKÇEARSLAN ÇİFTÇİ

Ankara Üniversitesi

Sağlık Bilimleri Fakültesi

Prof. Dr. Ömer EKMEKÇİ

İstanbul Üniversitesi

Hukuk Fakültesi

Prof. Dr. Zeki ERDUT

Dokuz Eylül Üniversitesi

İktisadi ve İdari Bilimler Fakültesi

Prof. Dr. Atilla GÖKÇE

Ankara Hacı Bayram Veli Üniversitesi

İktisadi ve İdari Bilimler Fakültesi

Prof. Dr. Banu UÇKAN HEKIMLER

Anadolu Üniversitesi

İktisadi ve İdari Bilimler Fakültesi

Prof. Dr. Cemal İYEM

Aydın Adnan Menderes Üniversitesi

Söke İşletme Fakültesi
Prof. Dr. İlknur KILKIS

Bursa Uludağ Üniversitesi

İktisadi ve İdari Bilimler Fakültesi

Prof. Dr. Handan KUMAŞ

Pamukkale Üniversitesi

İktisadi ve İdari Bilimler Fakültesi

Prof. Dr. Umut OMAY

İstanbul Üniversitesi

İktisat Fakültesi

Prof. Dr. Kamil ORHAN

Pamukkale Üniversitesi

İktisadi ve İdari Bilimler Fakültesi

Prof. Dr. Serap PALAZ

Bandırma Onyedi Eylül Üniversitesi

İktisadi ve İdari Bilimler Fakültesi

Prof. Dr. Faruk SAPANCALI

Dokuz Eylül Üniversitesi

İktisadi ve İdari Bilimler Fakültesi

Prof. Dr. Filiz Elmas SARAC

Ankara Hacı Bayram Veli Üniversitesi

İktisadi ve İdari Bilimler Fakültesi

Prof. Dr. Ferda YERDELEN TATOĞLU İstanbul Üniversitesi

İktisat Fakültesi

Prof. Dr. Aysen TOKOL

Bursa Uludağ Üniversitesi

İktisadi ve İdari Bilimler Fakültesi

Prof. Dr. Suat UĞUR

Çanakkale Onsekiz Mart Üniversitesi

Biga İktisadi ve İdari Bilimler Fakültesi

Prof. Dr. Handan YOLSAL

İstanbul Üniversitesi

İktisat Fakültesi

Doç. Dr. Erdem CAM

Ankara Üniversitesi

Siyasal Bilgiler Fakültesi
Doç. Dr. Hamdi EMEÇ

Dokuz Eylül Üniversitesi

İktisadi ve İdari Bilimler Fakültesi

Doç. Dr. Furkan EMIRMAHMUTOĞLU Ankara Hacı Bayram Veli Üniversitesi İktisadi ve İdari Bilimler Fakültesi

Doç. Dr. Aycan HEPSAĞ

İstanbul Üniversitesi

İktisat Fakültesi

Doç. Dr. Recep KAPAR

Muğla Sitkı Koçman Üniversitesi

İktisadi ve İdari Bilimler Fakültesi

Doç. Dr. Serdar KURT

Çanakkale Onsekiz Mart Üniversitesi

Biga İktisadi ve İdari Bilimler Fakültesi

Doç. Dr. Banu METİN

Ankara Hacı Bayram Veli Üniversitesi

İktisadi ve İdari Bilimler Fakültesi

Doç. Dr. Nagihan DURUSOY ÖZTEPE Pamukkale Üniversitesi

İktisadi ve İdari Bilimler Fakültesi

Doç. Dr. Ramazan ŞAHIN

Gazi Üniversitesi

Mühendislik Fakültesi

Doç. Dr. Özgür TOPKAYA

Çanakkale Onsekiz Mart Üniversitesi Biga İktisadi ve İdari Bilimler Fakültesi

Doç. Dr. Özlem YORULMAZ

İstanbul Üniversitesi

İktisat Fakültesi

Dr. Öğr. Üyesi Ömer DORU

Mardin Artuklu Üniversitesi

İktisadi ve İdari Bilimler Fakültesi

Dr. Öğr. Üyesi Özlem GÖKTAŞ

İstanbul Üniversitesi

İktisat Fakültesi

Dr. Cihan Serhat KART

Ankara Üniversitesi

Ayaş Meslek Yüksekokulu 


\section{SAYI DEĞERLENDİRME ISTATISSTIKLERİ}

EVALUATION STATISTICS FOR THIS ISSUE

Toplam gelen makale başvurusu

Yayına kabul edilen makale sayısı

Hakem süreci devam eden makale sayısı

Red edilen makale sayıs

Ön inceleme aşamasında red edilen makale sayısı

Makale kabul oranı
Number of received manuscript

39

Number of accepted manuscript

Under consideration

Rejected after evaluation

Rejected before evaluation

2

Accepted manuscript rate

$\% 35$ 
İnceleme Makalesi - Review Article

\section{Çalışanların 6331 Sayılı Kanundan Doğan Yükümlülükleri ve Yükümlülükleri İhlalin Sonuçları}

\section{Employees' Obligations due to Law No 6331 and the Results of Behavior Against Obligations}

\author{
Kübra DEMIR* \\ (iD) 0000-0002-2073-5085
}

Sosyal Güvenlik Dergisi / Journal of Social Security

Cilt: 10 Say1: 2 Y1l: 2020 /Volume: 10 Issue: 2 Year: 2020

Sayfa Aralığı: 393-412 / Pages: 393-412

DOI: 10.32331/sgd.841004

\section{ÖZ}

İş sağlığı ve güvenliğinin sağlanması için işverenlerin yerine getirmesi gereken birtakım yükümlülükler vardır. İşverenlerin yanında çalışanların da bu konuda uyması gereken önemli yükümlülükleri bulunmaktadır. 6331 sayılı İş Sağlığ1 ve Güvenliği Kanunu'na göre çalışanlar aldıkları eğitim doğrultusunda kendilerinin ve yaptıkları işten etkilenen diğer çalışanların sağlık ve güvenliklerini tehlikeye düşürmemekle yükümlüdürler. 6331 sayılı Kanun'un 19.maddesinde çalışanların yükümlülükleri düzenlenmiştir. Bu hüküm dışında Kanun'un 28. maddesinde de çalışanların bağımlılık yapan maddeleri kullanmalarına ilişkin düzenleme getirilmiştir. Çalışma kapsamında ilk olarak 6331 sayılı Kanun kapsamında "çalışan" kavramı açıklanmaya çalışılmıştır. Daha sonra çalışanların Kanundan doğan yükümlülükleri incelenmiştir. Son olarak yükümlülüklerine aykırı davranan çalışanların ne gibi yaptırım ile karşılaşacakları çeşitli kanunlar açısından ele alınmıştır.
Anahtar Sözcükler: Çalışan, iş sağlığı ve güvenliği, 6331 sayılı Kanun, işveren

\section{ABSTRACT}

Employers have some obligations to ensure occupational health and safety. In addition to employers, employees also have important obligations to comply with. According to Occupational Health and Safety Law No. 6331, employees are obliged not to endanger the health and safety of themselves and other employees affected by their work in line with the training they receive. Article 19 of Law No. 6331 regulates the obligations of employees. Apart from this provision, again in Article 28 of the Law, the regulation on the use of addictive substances has been introduced. In this study, the concept of "employee" is tried to be explained in Law No. 6331. Then the obligations of the employees arising from the law were examined. Finally, the sanctions faced by those who violate their obligations were examined in terms of various laws.

Önerilen atıf șekli: Demir, K. (2020). Çalışanların 6331 Sayılı Kanundan Doğan Yükümlülükleri ve Yükümlülükleri

İhlalin Sonuçları. Sosyal Güvenlik Dergisi (Journal of Social Security). 10(2). 393-412

\footnotetext{
* Arş. Gör., Sivas Cumhuriyet Üniversitesi, Hukuk Fakültesi,

İş ve Sosyal Güvenlik Hukuku Anabilim Dalı, koz@cumhuriyet.edu.tr
} 


\section{GİRiş}

Sağlıklı ve güvenli bir ortamda çalışma ihtiyacı, bireylerin temel hak ve özgürlüklerinden olan yaşam hakkı ile sıkı bir ilişki içerisindedir. Bu ihtiyaç, insanlık tarihi kadar eskiyken bu durumun sosyal ihtiyaç olarak kabul görmesi oldukça yeni bir durumdur. (Balkır, 2012a: 58). İş sağlığı ve güvenliğinin (İSG) yaşam hakkıyla son derece sıkı bir ilişki içerisinde olması konuyu yalnızca işverenin veya çalı̧̧anın sorunu olmaktan çıkarır. İSG ilişkisi, devletin de taraf olduğu üçlü bir hukuki ilişki olarak değerlendirilebilir (Kabakçı, 2009: 250).

Devlet, sosyal düşüncelerle iş ilişkisine işçiyi koruma düşüncesiyle müdahale eder. Devletin çalışanların sağlıklı fiziksel ortamda gerçekleştirecekleri çalışmalara müdahalesi, işçi ve işveren arasındaki dar bir ilişki kapsamında değerlendirilmemelidir. Çalışanların çalışma ortamından kaynaklanan hayati tehlikelere karşı korunması işçi-işveren ilişkisinin ötesinde, kamusal zorunluluktur (Kabakçı, 2009: 253).

Yaşam hakkının korunması, çalışanların sağlık ve güvenliğinin sağlanması yalnızca özel hukuk kuralları çerçevesinde taraflara yüklenecek borçların yerine getirilmesi ile gerçekleştirilemez. İSG esasında özel hukuk alanının dışına taşmıştır ve kamu hukuku kuralları ile örülmüştür. İSG'ye kamu hukuku niteliği kazandıran durum şüphesiz devletin, tarafların ilişkisine olan müdahalesidir (Kabakçı: 2009: 255-261). İSG kurallarının kamu hukuku niteliği taşıyan yönü doğrultusunda devletin görevi yalnızca mevzuat hazırlama, mevzuatın uygulanıp uygulanmadığını denetlemek değildir. Kamu kurumlarında başarılı İSG önlemlerinin uygulanması ve bunların geliştirilmesi adına öncü rol oynamak devletin bu alandaki en büyük sorumluluklarındandır (Erol, 2015: 116).

6331 sayılı İş Sağlığı ve Güvenliği Kanunu (İSGK) yürürlüğe girene kadar hukukumuzda İSG'ye ilişkin ayrı Kanun bulunmamaktaydı. Konuya ilişkin koruyucu mevzuat hükümlerinin bir kısmı 4857 sayılı İş Kanunu'nda² (İK) yer almaktayken İSG alanındaki kapsamlı düzenlemeler esasen 1973 yılında Bakanlar Kurulu kararı ile kabul edilen İşçi Sağlığı ve İş Güvenliği Tüzüğü'nde ${ }^{3}$ düzenlenmişti. 4857 sayılı Kanunda bulunan İSG hükümlerinin bu alana kamu hukuku karakterini kazandıran özelliği, devletle işveren arasındaki ilişkinin, devletin öngördüğü yükümlülüklere işverenin uyması şeklinde oluşturulmasıdır. Kanunda işçilere İSG alanında aktif olmalarını gerektiren herhangi yükümlülük getirilmemişti. İşçilerin yalnızca ISG alanında alınan önlemlere uyma yükümlülüğü bulunmaktaydı (Kabakçı, 2009: 261).

Çalışanların pasif rolünün ortadan kaldırılması bir yana ISSG alanında mevzuat kaynaklarının dağınıklığından doğan sıkıntıların giderilmesi için temel kanunun varlığına ihtiyaç duyulmuştur (Gerek, 2013: 10). Bu ihtiyaç Avrupa Birliğinin (AB) 89-391 Sayılı Çerçeve Yönergesinde ${ }^{4}$ yer alan hükümlerden doğmaktadır. Yönerge, İSG'ye ilişkin sınırlı istisnalar getirerek tüm çalışanların sağlıklı ve güvenli bir ortamda çalışmasını hedeflemiştir (md.2). İSG yalnızca işçiyle işveren düzeyinde değil toplumun tamamını doğrudan ilgilendiren ulusal ve uluslararası düzeyde ele alınması gereken önceliktir (Balkır, 2012b: 20).

6331 sayılı İSGK'nın yürürlüğe girmesiyle beraber İSG alanına yönelik geniş ve ayrıntılı düzenlemeler getirilmiş, Kanunun kapsamı sınırlı istisnalar dışında oldukça geniş tutularak,

\footnotetext{
${ }^{1}$ RG. 28339. 20.06.2012.

${ }^{2}$ RG. 25134. 22.05.2003.

${ }^{3}$ RG. 14765. 11.01.1974.

4 AB'nin Kurucu Antlaşması'nın 137. maddesine dayanılarak çıkarılan İSG'ye ilişkin yönergelerden birisi olan "Çalışanların Sağlık ve Güvenliklerini İyileştirmeye Yönelik Önlemler Alınmasına İlişkin Çerçeve Yönerge" başlığı taşıyan bu düzenleme 12.06.1989'da Bakanlar Konseyi tarafından onaylanmış, 01.01.1993 tarihinde yürürlüğe girmiştir.
} 
iç hukukta İSG alanında AB mevzuatına uyum yakalanması hedeflenmiştir. Kanun'un sektör ayırt etmeksizin tüm alanlarda uygulanacağına ilişkin kapsam maddesi, 89/391 sayılı Yönergenin 2. maddesi ile uyumlu olarak düzenlenmiştir.

Sanayi toplumundan bilgi toplumuna geçişle birlikte teknolojik gelişmelerdeki baş döndürücü hız ve atipik istihdam modellerinin gelişmesiyle birlikte geleneksel işçi tanımı, çalışma hayatı açısından oldukça dar bir kavram olarak kalmıştır. Gelişmiş ülkelerde işçi kavramından çok çalışan kavramı ön plana çıkmaktadır ve herhangi bir meslekten kaynaklanan bir risk varsa bu risklere karşı tüm çalışanların korunması amaçlanmaktadır (Baloğlu, 2015: 104, 105).

6331 sayılı İSGK ile birlikte İSG hizmetlerinden faydalanan kişilerin kapsamı genişletilmiş aynı zamanda İSG hizmetlerinden yararlanan tüm çalışanlara önlemlere uyma yükümlülüğü dışında İSG'yi sağlama noktasında aktif rol yükleyen birtakım yükümlülükler getirilmiştir.

İşyerlerinde İSG ile ilgili yönetim sistemi oluşturmak yalnızca işverenin sorumluluğunda görülmemelidir. Çalışanlar bu sorumluluğa dâhil olacak şekilde İSG'yi sağlama adına işbirliği içerisinde hareket etmelidir. 6331 sayılı İSGK'da işverenlere yüklenen yükümlülüklerin çalışanların hakkı olduğu gerçeği ise unutulmamalıdır (Atan, vd., 2017:20-21).

\section{I- 6331 SAYILI ISGK KAPSAMINDA ÇALIŞAN KAVRAMI VE KAVRAMA YÖNELIK SORUNLAR}

6331 sayılı İSGK'da çalışan kavramı; "Kendi özel kanunlarındaki statülerine bakılmaksızın kamu veya özel işyerlerinde istihdam edilen gerçek kişi” olarak tanımlamıştır (md.3/I, b). Kanun, kamu ve özel sektör ayırmaksızın çalışan tüm kesimle ilgili hüküm ve sonuçlar doğurmaktadır. İSGK'nın kapsamı dışında kalan kişiler ve faaliyetler ise "Kapsam ve İstisnalar" başlıkl1 2. maddede sınırlı bir şekilde belirtilmişstir.

İSGK' da “çalışan” kavramının kapsam bakımından geniş tutulması öğretide tartışmalara neden olmuştur. Düzenlemenin isabetsiz olduğunu savunan görüşe göre; Kanunda "çalışan" kapsamının geniş tutulması kamu hukuku ve özel hukuk kurallarına ilişkin uygulamalar göz önüne alındığında hukuki açıdan sorun teşkil edebilecektir. Kanunda yer alan düzenlemelerin memur statüsünde çalışan ve işçi statüsünde çalışan herkes için aynı hükümler içermesi fakat bu kişilerin işverenleriyle aralarında kurmuş oldukları hukuki ilişkilerinin tabi olduğu hukuk dallarının birbirinden farklı olması pek çok farklılığı beraberinde getirecektir. Kamu hukuku ve özel hukuk yaptırımları birbirinden farklılık göstermektedir. Kanunda çalışanlara aynı yükümlülüklerin getirilmesi ancak yükümlülüklere aykırı davranmanın farklı yaptırımlarla düzenlenmiş olması, aynı işyerinde farklı statüde çalışan kişiler açısından eşitsizliğe neden olacaktır. Özel hukuk ve kamu hukuku açısından temel kavramlara yönelik tanımlamalarda yer alan farklılıkların yanı sıra her iki hukuk dalına ait uyuşmazlıkların farklı yargı kollarında görülmesi çalışanlar açısından farklı sonuçların doğumuna sebep olacaktır. Özel hukuka ilişkin uyuşmazlıklar, adli yargıda medeni usul hukuku kuralları çerçevesinde görülürken; kamu hukuku kapsamında uyuşmazlıklar, idari yargılamaya hâkim olan ilkeler ve idari yargılama usulüne ilişkin kurallar çerçevesinde incelenmektedir (Özdemir, 2014: 107, 108). İstanbul Tabip Odası tarafından yapılmış olan açıklamada memurlar için çıkarılmış sigorta yasası bulunmadığından, memurların iş kazası ve meslek hastalığı sigortası hakkının bulunmadığı belirtmiştir. Dolayısıyla 6331 sayılı İSGK ile tanımlanan çalışan kavramının gerçeği yansıtmadığı ileri sürülmüştür (İstanbul Tabip Odası, 2015). Hal böyleyken aynı 
kuralların farklı yapıda örgütlenmiş kişilere uygulanması çeşitli sorunlara yol açacaktır (Y1lmaz, 2013: 44).

Türkiye'de çalışanların büyük çoğunluğu işçi statüsünde çalışanlar oluşturmaktaysa da memurların da Kanun kapsamında tutularak, Kanun'un hiçbir ayrımda bulunmaksızın kamu ve özel sektöre ait bütün işlere, işyerlerine uygulanmasının isabetli olduğunu savunan görüşler de bulunmaktadır (Gerek, 2013: 12). İş Kanunu, Basın İş Kanunu, Deniz İş Kanunu, Devlet Memurları Kanunu (DMK) gibi düzenlemelerdeki farklılıkların nasıl giderileceği konusunda var olan belirsizliğin uygulama açısından sıkıntı teşkil edecek olmasından dolayı Kanun'un sınırlı istisnalarla herkesi kapsamına alması mevzuat dağınıklıklarının giderilmesinde önemli bir adım olarak görülmüştür. Bahsi geçen kanunlar bakımından İSG alanında ayrıntılı düzenlemeler yapılmamış olması da bu görüş doğrultusunda İSG kapsamına tüm çalışanların alınmasının isabetli olduğu sonucunu doğurmaktadır (Baloğlu, 2013: 107).

İstisnalar hariç tüm çalışanların İSGK kapsamına alınması, tüm çalışanların sağlık ve güvenliğini ve temelde yaşam hakkını sağlamaya yönelik olumlu bir gelişme olarak görülebilir. Ancak iş hukuku, sözleşme hukukuna ait özellikler taşımaktadır. Tarafların eşit olduğu özel hukuk sözleşmelerinde kişiler eşit hak ve menfaatlere sahiptir. Kamu hukukunda tek taraflı, genel, objektif ve kişilik dışı bir hukukî durum söz konusudur. Öğretide iş hukukuna özgü kurallar bir kenara bırakılırsa İSG'ye ilişkin kuralların niteliğinin kamu hukuku ile şekillendiği savunulmuştur. Buna göre; İSG denilince akla kamu hukuku kurallarına göre yapılandırılmış emredici düzen gelmektedir. İş hukukunda işçi ve işveren arasındaki ilişki genel itibariyle nispi emredici kurallarla şekillenmişse de İSG kuralları nispi emredici kurallar dışında daha çok mutlak nitelik taşımaktadır. Bu kurallar işçi ve işverenin karşılıklı uyması gereken ve sözleşmeden doğan borç niteliği taşımasının yanında kamu hukukundan doğan yükümlülük olarak da değerlendirilmelidir. İSG kuralları çalışma koşulları açısından çalışanın korunmasından ziyade onun doğrudan varlığını, yaşam hakkını güvence altına alan kurallardır. Bu tespitler ışığında işçi ve işveren arası ilişkiyi ele alsa dahi İSG kuralları bağımsız kamu hukuku dalını oluşturmaktadır. Sosyal güvenlik hukukunun kamu hukuku niteliği konusunda herhangi bir şüphe bulunmuyorsa, İSG hukuku kurallarının da kamu hukuku dalı olarak kabul görmesi kaçınılmazdır (Kabakçı, 2009: 264, 265).

\section{II- GENEL OLARAK ULUSLARARASI VE ULUSAL DÜZENLEMELERDE ÇALIŞANLARIN YÜKÜMLÜLÜKLERİ}

Ulusal ve uluslararası alanda yapılan çalışmalar meydana gelen iş kazalarının büyük oranda insan kaynaklı olduğunu göstermektedir. İşyerinde iş kazalarını önlemek adına alınacak fiziki tedbirlerin yanında önemli olan bu tedbirlerin çalışanlar tarafından nasıl algılandığıdır. Çalışanlarda oluşan İSG algısı işverenler tarafından alınan ve mevzuat kapsamında öngörülen tedbirlerin etkili bir şekilde uygulanması noktasında kilit noktayı oluşturmaktadır. Çalışanların konulan kuralları algılama düzeyleri geliştikçe İSG bilinci gelişecek, iş kazaları ve meslek hastalıklarının sayısında azalma meydana gelecektir (Atan, vd., 2017: 31).

ILO standartları İSG'yi sağlamaya yönelik koruyucu politikalarda çalışanın rolünü özellikle vurgulamaktadır. İşyerinde çalışanların katılımı; başarılı ISS yönetiminde, iş kazaları ve meslek hastalıklarını azaltmada temel ve kilit rol olarak tanımlanmıştır. İşyerindeki uygulamalardan kaynaklanan sorunlar hakkında bilgi sahibi olan ve işyerindeki riskler ve onların muhtemel çözüm yolları hakkında bilgi temin edilebilecek kişiler ilk aşamada çalışanlardır. ILO'nun 155 sayılı İş Sağlığı ve Güvenliği ve Çalışma Ortamına İlişkin 
Sözleşmesi ve 164 No'lu tavsiye kararı, işyerindeki önleme ve kontrol ilkelerinin uygulanmasında çalışanların katılımını sağlamaktadır. İSG'nin temel şartını işveren, çalışanlar ve çalışan temsilcileri arasındaki işbirliğine bağlamakta ve tarafları bu işbirliğine zorlamaktadır. ILO standartlarına göre çalışanların ve çalışan temsilcilerinin yükümlülükleri kapsamında; kişisel koruyucu donanımların kullanımı sağlanmalı, çalışanlar sağlık ve güvenlik kurallarına uymalıdırlar, kendi güvenlikleri ve kendi hareketlerinden veya hatalarından dolayı çalışanların güvenliklerini tehlikeye düşürmemek için gerekli özeni göstermelidirler. İSG eğitimleri ve bilinçlendirme faaliyetlerine katılmalıdırlar. İSG ilkelerini uygulamada, işverenleriyle işbirliği içerisinde olmalıdırlar. İşyerinde meydana gelen işle ilgili kaza ve yaralanmaları bildirmelidirler. İşyerinde ciddi ve yakın bir tehlike varsa ve bu tehlikelerin neden olabileceği olaylar varsa bu konular hakkında denetim görevlilerine şikâyette bulunmalıdırlar (Workers' Participation, 2015).

89/391 sayılı Çerçeve Yönerge ekonomik faaliyet ayrımı yapmaksızın tüm çalışanların uyması gereken yükümlülükleri belirtmiştir. Yönergeye göre çalışanlar; makineleri, araç ve gereçleri, tehlikeli aletleri ve diğer koruyucu aletleri ve kişisel koruyucu aletleri doğru kullanmakla yükümlüdür. İşyeriyle ilgili acil ve tehlikeli bir durum söz konusu olduğunda veya korumaya yönelik bir eksiklik olduğunda durumu işverene bildirmekle yükümlüdürler. İSG'yi sağlamak amaciyla işverenle işbirliği içerisinde hareket etmelidirler. İşçiler için oluşturulacak risksiz ve güvenli çalışma şartları ve çalışma çevresi de işveren tarafından garanti altına aldırılmalıdır (md. 13).

Çalışanlar işyerinde alınan her türlü önleme uymakla yükümlüdürler. Türk Borçlar Kanunu'nun $^{5}$ (TBK), 399. maddesi işçinin düzenlemelere ve talimatlara uyma borcunu düzenleyerek, işverenin yapmış olduğu düzenlemelere, özel talimatlara uymakla yükümlü olduğunu belirtmiştir. TBK'nın 396. maddesinde işçinin borçları kapsamında yüklendiği işi özenle yapma borcu ve işverenin haklı menfaatinin korunmasında sadakatle davranma yükümlülüğü düzenlenmiştir. Maddenin 2. fikrasında işçinin işverene ait makineleri, araç ve gereçleri, teknik sistemleri, tesisleri ve taşıtları usulüne uygun kullanma yükümlülüğü ve işin görülmesi amaciyla kendisine teslim edilen malzemeye özen gösterme yükümlülüğü düzenlenmiştir. Tüm bu yükümlülükler kapsamında işçinin sorumluluğunun niteliği TBK kapsamında kusurlu sorumluluk olarak nitelendirilmiştir. Kanun'un 400. maddesinde yer alan düzenlemeye göre işçi, işverene kusuruyla verdiği her türlü zarardan sorumludur. Düzenlemenin devamında işçinin sorumluluğu için esas alınacak krtiterler de belirtilmiştir. İşin tehlikeli olup olmaması, uzmanlık ve eğitim gerektirip gerektirmemesi ve işçinin işveren tarafından bilinen veya bilinmesi gereken yetenek ve niteliklerinin de göz önünde bulundurulacağı ifade edilmiştir (md. 400/2).

İSGK'nın 19. maddesi çalışanların yükümlülüklerini düzenlemiştir. Çalışanların ilk etapta diğer çalışanların sağlık ve güvenliklerini tehlikeye düşürmeme yükümlülüğü vardır. $\mathrm{Bu}$ yükümlülüğün dışında işyerindeki iş ekipmanlarını sağlık ve güvenlik kuralına uygun kullanmak, kişisel koruyucu donanımları usulüne uygun kullanmak, işyerinde kullanılan araç ve gereçlerle ilgili ciddi ve yakın bir tehlike varsa bunları ilgili kimselere haber vermekle yükümlüdürler. Çalışanlar İSG kurallarının uygulanmasını sağlamak adına gerek çalışan temsilcileri gerekse diğer çalışanlarla işbirliği yapmakla yükümlüdürler.

İSGK'dan önce İSG'ye dair hükümlerin yer aldığı 4857 sayılı İK kapsamında işçilerin İSG'ye ilişkin pasif bir rol üstlendiği ve uyma borcu olarak düzenlenen yükümlülükleri, İSKK daha ayrıntılı olarak açıklanmaya çalışılmıştır (Alpagut, 2014: 44).

${ }^{5}$ RG. 27836. 04.02.2011. 


\section{III- ÇALIŞANLARIN 6331 SAYILI İSGK'DAN DOĞAN YÜKÜMLÜLÜKLERİ}

\section{A- Çalışanların İşveren Tarafından Verilen Eğitim Kapsamındaki Yükümlülükleri}

Çalışanlara verilecek İSG eğitiminin usul ve esaslarına yönelik düzenlemeler 28648 sayılı Resmi Gazete'de yayımlanan Çalışanların İş Sağlığı ve Güvenliği Eğitimlerinin Usul ve Esasları Hakkında Yönetmelikte düzenlenmiştir.

İş sözleşmesinden doğan gözetme borcu, işvereni işyerinde çalışanın yaşam, sağlık ve beden bütünlüğünün korunması için gerekli önlemleri almakla yükümlü kılar. Yargıtay Hukuk Genel Kurulu tarafından verilen kararda ${ }^{6}$ "İşçinin yapılan iş nedeniyle alacağı İSG eğitimi bir kısım mevzuat hükümlerini içeren bilgilerin kendilerine verilmesini değil, eylemli olarak bu bilgilerin aktarımı ve öneminin kavratılmasıyla sağlanabilir. Sonraki aşamaysa gerekli önlemlerin alınması ve denetlenmesidir." denilerek yalnızca yazılı kuralların İSG önlemleri için yeterli olmayacağı vurgulanmıştır. İşveren mevzuatta öngörülmemiş ancak bilimsel ve teknolojik gelişmelerin gerekli kıldığı diğer İSG önlemlerini de almak zorundadır. Gerçek anlamda iş güvenliğinin sağlanması her şeyden önce bireylerde oluşturulacak İSG bilincine bağlıdır. Hukukî güvence mekanizmaları ne kadar iyi olursa olsun toplum ve kişilerde bu mekanizmaları işletme konusunda yeterli bir bilinç oluşmamışsa güvenceler kâğıt üzerinde kalmaktan öteye gidemez (Süzek, 2006: 511, 512).

Çalışanların İş Sağlığı ve Güvenliği Eğitimlerinin Usul ve Esasları Hakkında Yönetmeliğe göre işveren tarafından ISG'nin sağlanmasına yönelik eğitimlerin verimli olması için eğitimlerde, eğitime katılacakların çalıştıkları işe uygun olan içeriklerin seçilmesi gereklidir. Eğitimin amacı, çalışanlarda İSG'ye yönelik davranış değişikliğini sağlamak olmalıdır ve verilen bilgilerin öneminin çalışanlarca kavranılması sağlanmalıdır (Kurt, 2013: 160). Ülkemizde 2014 yılında Manisa'nın Soma ilçesinde meydana gelen, Türkiye tarihinin en çok can kaybı yaşanan maden kazası olarak kayıtlara geçen Soma faciasında hayatta kalan pek çok işçi, işe girmeden önce kursta edindikleri bilgileri uygulayarak ölümden kurtulmuşlardır. Kaza sırasında madende mahsur kalan işçilerden Selahattin Şen yaptığı açıklamada "Bir emniyet şeridi astım. O şerit havaya göre kıpırdıyordu. Sürekli onu takip ettim. Saat 21'e doğru o şeridin yönü değişmeye, hava gelmeye başladı. Ondan sonra biz orada kalan kişiler yavaş yavaş toparlandık, kendimize geldik, sonra da yukarıdan kurtarıcı ekipler geldi onlarla beraber yeryüzüne çıktık. Kötü bir olay yaşadık. Bizi kurtaran o demirler oldu. O demirlerden sürekli oksijen aldık. Hava değil oksijen aldık. Bunu ben yıllardan beri biliyordum. Zonguldak'ta madencilik okulunda bunun kursunu da gördük. 40'ın üzerinde arkadaş bu sayede kurtulduk. Saat 00:06'da dışarı çıktım" diyerek, aldıkları eğitimin ve eğitim doğrultusunda hareket etmenin ne derece önemli olduğunu göstermiştir (Sabah Gazetesi, 2015).

İşverenlerin eğitim verme yükümlülüğüne karşılık çalışanların uygulamaya konulan eğitim programları çerçevesinde İSG eğitimlerine katılma, eğitimlerde edindiği bilgileri yaptığ 1 iş ve işlemlerde uygulama, bu konudaki talimatlara uyma yükümlülükleri bulunmaktadır (Yön. md. 9). Yükümlülüklerin yerine getirilmemesi, iş kazası ve meslek hastalıklarında kusur oranlarının tespitinde dikkate alınır. Yargıtay kusur oranını tespit ederken yalnızca işverenin yükümlülüğünün ihlalini değil çalışanların da uyması gereken yükümlülüklerin ihlalini dikkate almaktadır. Buna göre "ISG açısından işverenin aldığı ve almadığı tedbirlerin belirlenmesi ve sonucuna göre işverenin kusurunun saptanması ve sigorta olayına maruz

${ }^{6}$ Yarg. HGK. 16.06.2004. E: 2004/21365. K: 2004/369. 
kalan sigortalının bu tedbirlere uyup uymadığının, başkaca bir kusuru bulunup bulunmadığının belirlenmesi ve kusurun buna göre dağıtılması gerekir.” (Kılıç, 2006: 60)7.

4857 sayılı Kanunda geçici işçiye verilmesi gereken ISG eğitimleriyle ilgili özel bir hüküm bulunmaktadır. Geçici işveren, işçiye İSGK'nın 17. maddesinde öngörülen eğitimleri vermekle yükümlüdür, geçici işçi de bu eğitimlere katılmakla yükümlüdür. (İK md. 7/9) (Çelik, Caniklioğlu ve Canbolat, 2019: 244). Geçici işçilerin İSG konusunda alacakları eğitime dair düzenleme Yönetmelikte yer almıştır. Geçici işverenin, geçici işçilerin eğitiminden sorumlu olduğu ifade edildikten sonra ayrıca geçici işçilerin işyerindeki risklere karşı bilgilendirilmesi ifade edilmiştir (Yön. md. 5/2).

Alt işveren asıl işveren ilişkisi kurulmuş olan işyerlerinde ise her işverenin kendi çalışanlarının İSG eğitiminden sorumlu olduğu ifade edilmiştir. Bu ilişskinin kurulduğu işyerlerinde, alt işveren çalışanlarının İSG eğitimlerinden, asıl işverenin bilgilendirilmesi gerektiği belirtilmiştir. Asıl işveren, alt işveren işe başlamadan önce işyerindeki risklere karşı bilgi vermekle yükümlü tutulmuştur. (Yön. md. 5/3). Bu yükümlülük alt işverenin işçilerinin de işyerinde alınan önlemlere uymak zorunda olduğunu göstermektedir.

\section{i) İşyerindeki Araçları Kullanmaya İlişkin Yükümlülük}

6331 sayılı İSGK kapsamında yer alan düzenlemede çalışanlar işyerindeki makine, cihaz, araç, gereç, tehlikeli madde, taşıma ekipmanı ve diğer üretim araçlarını kurallara uygun şekilde kullanmak, bunların güvenlik donanımlarını doğru olarak kullanmak, keyfi olarak çıkarmamak ve değiştirmemekle ve kendilerine sağlanan kişisel koruyucu donanımları doğru kullanmak ve korumakla görevlidirler (md. 19/2, a, b).

Çalışanlar verilen eğitim ve talimatlara uygun olarak kendilerine tahsis edilen araç ve gereçleri usulüne uygun kullanmalıdır ve güvenlik araçlarını ve tertibatlarını rastgele değiştirmek ve çıkarmaktan kaçınmalıdırlar (md. 19/2). Çalışanların iş görme borçlarını yerine getirmeleri için tahsis edilmiş olan makine, araç ve gereçleri özen göstererek usulüne uygun kullanma yükümlülükleri sadakat borcunun bir sonucudur. Bu borç TBK'nın 396. maddesinde işin görülmesi için kendisine tahsis edilen malzemeye özen gösterme yükümlülüğü olarak da yer almaktadır (Senyen Kaplan, 2014: 39). Yargitay 2011 yılında verdiği kararda "Şoför olarak çalışan işçiye işveren tarafından İSG eğitimi kapsamında; emniyet ve kaza önleme tedbirleri, sürüş teknikleri, emniyet kemeri takma zorunluluğu ve önemiyle, ilk yardım konularında verilen eğitime rağmen, işçinin emniyet kemeri takmadığı tespit edilmiş ve bunun üzerine uyarılmak istenen işçi uyarıyı tebliğ almaktan imtina etmiştir. Bu durumda Yüksek Mahkeme emniyet kemeri takmadan araç kullanan şoförün olaydaki bu davranışını ağır kusur ve objektif olarak iş güvenliğini tehlikeye düşürecek haldir." ifadesini kullanmıştır (Mollamahmutoğlu, Astarlı ve Baysal, 2014, 1369) ${ }^{8}$.

TBK'da yer alan düzenleme İSGK'ya paralel bir düzenlemedir. Buna göre; işçinin işverene ait makineleri, araç ve gereçleri, teknik sistemleri, tesisleri ve taşıtları usulüne uygun olarak kullanmak ve bunlarla işin görülmesi için kendisine tahsis edilmiş olan malzemeye özen göstermekle yükümlülüğü vardır. Söz konusu yükümlülüğün işçinin sadakat borcunun neticesi olduğu ifade edilmişti (Senyen Kaplan, 2014: 39). İşyerinde kullanılan malzeme iş sahibi tarafından verildiğine göre işçinin malzemeyi özenle kullanma, bu konuda iş sahibine hesap verme ve artan malzemeyi iade yükümlülüğ̈̈ bulunmaktadır (Yağız, 2011: 524).

Kişisel koruyucu donanımlar, çalışanların iş kazası ve meslek hastalıklarına uğramalarını önlemek üzere çalışılan yerin özelliğine ve yürürlükteki mevzuata göre çalışma süresince

\footnotetext{
${ }^{7}$ Yarg. 10. HD. 18.12.1984. E: 6375. K: 6447.

${ }^{8}$ Yarg. 9. HD. 12.12.2011. E: 2009/37034. K: 2011/47935.
} 
kullanılma zorunluluğu olan malzemelerdir. Kişisel korunma araçları, işyerinde alınan tüm güvenlik tedbirlerine rağmen önlenemeyen tehlikelere karşı korunmak için kullanılırlar (Yiğit, 2013: 345). İSGK'da işçiler kendilerine sağlanan kişisel koruyucu donanımları doğru kullanmakla yükümlü kılınmışlardır. (md. 19/2-b) Kişisel Koruyucu Donanımların İşyerinde Kullanılması Hakkındaki Yönetmelikte ${ }^{9}$ de işçiler; işverenin vereceği bilgi ve talimatlar doğrultusunda kişisel koruyucu donanımları doğru kullanmak, korumak ve uygun şekilde muhafaza etmekle yükümlüdürler (Yön. md. 8/2).

\section{ii) Güvenlik Yönünden Tehlikeli Durumları Haber Verme Yükümlülüğü}

Çalışanların yükümlülüklerinden diğerini; işyerindeki makine, cihaz, araç, gereç, tesis ve binalarda sağlık ve güvenlik yönünden ciddi ve yakın tehlikeyle karşılaştıklarında ve koruma tedbirlerinde bir eksiklik gördüklerinde, işverene veya çalışan temsilcisine derhal haber verme oluşturmaktadır (İSGK md. 19/2-c). Tehlikenin yakın olması henüz tehlikenin gerçekleşmemiş ancak çok kısa bir sürede gerçekleşecek olması olarak ifade edilebilir. Tehlikenin ciddi olması ise tehlikenin önemli ölçüde zarar veya hasar verme olasılığını anlatmaktadır. Bir başka ifadeyle tehlikenin ciddi olmasıyla işin normal riskinin üzerinde bir ağırlığa sahip olmasından bahsedilebilir (Özdemir, 2014: 415).

Söz konusu düzenleme de işçinin sadakat borcunun sonucudur. Sadakat borcunun içeriğini esasen Medeni Kanun'un 2. maddesi belirlemektedir. Sadakat borcunda işçiden beklenebilir ölçüde işverenin haklı menfaatlerinin korunması söz konusudur. İşçinin sağlığı, ekonomik ve mesleki geleceği, çalışma hakkı borcun sınırlarını oluşturur. İşyerindeki tehlikeli bir halden, makine ve tesisat arızalarından işvereni haberdar etme sadakat borcunun yapma davranışlarını içeren kısmını oluşturur (Senyen Kaplan, 2014: 40). Tehlikeyi haber verme çalışanlara getirilmiş bir yükümlülük olsa da bunun önünün açılması işveren tarafından işyerinde demokratik bir ortamı sağlamakla mümkün olacaktır (Özdemir, 2014: 441).

89/391 sayılı Çerçeve Yönerge'nin 11. maddesi güvenli iş sağlığı sisteminin gelişiminde çalışan katılımının önemini vurgulamıştır. İSG'nin sağlanmasıyla görevli işçi temsilcileri, çalışanların maruz kalacağı zararları hafifletmek ve/veya tehlikenin kaynağını yok etme hususunda teklifler verme ve önlem alınmasını isteme hakkına sahiptir (md. 11/3). İşçiler veya temsilcileri, İSG önlemlerinin yetersiz olduğunu düşünürlerse Kanunlara uygun olarak bu konuda yetkili makamlara müracaat edebileceklerdir (md. 11/6).

6331 sayılı İSGK'da yer alan düzenlemede: “İşveren, çalışanların kendileri veya diğer kişilerin güvenliği için ciddi ve yakın tehlike ile karşılaştıkları ve amirine hemen haber veremedikleri durumlarda; istenmeyen sonuçların önlenmesi için, bilgileri ve mevcut teknik donanımları çerçevesinde müdahale edebilmelerine imkân da sağlar. Böyle durumlarda çalışanlar, ihmal veya dikkatsiz davranışları olmadıkça yaptıkları müdahaleden sorumlu tutulamaz.” (md. 12/2).

\section{iii) İşbirliği Yapma Yükümlülüğü}

Teftişe yetkili makam tarafından işyerinde tespit edilen noksanlık ve mevzuata aykırılıkların giderilmesi konusunda işveren ve çalışan temsilcisiyle işbirliği yapma yükümlülüğü çalışanların İSGK' da sayılan yükümlülüklerinden bir diğeridir (md. 19/2-ç). Çalışanlar kendi görev alanında, İSG'nin sağlanması için işveren ve çalışan temsilcisiyle işbirliği yapmalıdır (md. 19/2-d). İş Sağlığ1 ve Güvenliği Hizmetleri Yönetmeliğinde ${ }^{10}$ çalışanların hak ve yükümlülüklerinin düzenlendiği 8. maddede çalışanların, İSG hizmetlerini yerine getirmek üzere işveren tarafından görevlendirilen kişi veya Ortak Sağlık ve Güvenlik Birimlerinin

\footnotetext{
${ }^{9}$ RG. 28695. 02.07.2013.

${ }^{10}$ RG. 28512. 29.12.2012. 
yapacağı çalışmalarda işbirliği içerisinde hareket edeceği düzenlenmiştir (Yön. md. 8/2-b). Aynı maddede teftişe yetkili makam tarafından işyerinde tespit edilen noksanlık ve ilgili mevzuatın aykırılıklarının giderilmesi konusunda işveren ve çalışan temsilcileri ile işbirliği yapmakla yükümlü olduğu ifade edilmiştir (Yön. md. 8/8-d).

Çalışanların İSG'ye katılımı ne ifade etmektedir? Çalışanlar ve yöneticiler ortak bir girişimle İSG alanında ne şekilde etkili önlemler alabilirler? Tüm bu soruların cevabı için EU-OSHA (OSHA, 2015) European Trade Union Confederation (ETUC) ile işbirliği içerisinde, çalışan ve çalışan temsilcileri için uygulama rehberi hazırlamıştır. İSG'de çalışan katılımı uygulama rehberi, çalışan ve işverenlerin birlikte çalışarak işyerindeki riskleri azaltmalarına yönelik yararlı bilgileri içermektedir. Çalışan ve işverenlerin hem birbirlerine karşı hem topluma karşı yasal zorunluluklarına ve ahlaki görevlerine rehberde yer verilmiştir. Söz konusu rehberde çalışan katılımının rolü tanıtılmaya çalışılmıştır (A Practical Guide, 2012: 10). Çalışanlar ve çalışan temsilcileri, iş nasıl yapılır ve yapılan iş onları ne şekilde etkiler gibi soruları cevaplandırabilirler. $\mathrm{Bu}$ sayede işyerlerinde kaza oranlarının ve risk seviyelerinin düşmesine yardımcı olabilirler. İSG'de çalışan katılımı; bir tarafta işverenin diğer tarafta çalışan veya çalışan temsilcilerinin olduğu basit ve çift taraflı bir süreci gerektirir. İşlemin taraflarını oluşturanlar birbirleriyle konuşarak fikir alışverişinde bulunmalı, birbirlerinin görüşlerini dinlemeli, paylaşılan görüşleri ve bilgileri araştırmalı, konuları zamanında tartışmalı ve görüşmeli, her kesimin görüşü göz önünde bulundurulmalı, birlikte karar almalı, birbirine güvenmeli ve sayg1 göstermelidir (A Practical Guide, 2012: 10-12).

Çalışanların sağlık ve güvenliğini sağlamada çalışan temsilcileri veya işverenle yapacakları işbirliği hastalık ve kaza oranlarının düşmesine yardımcı olur. Çalışanların katılımıyla yasal işlem tehdidi, kazaları azaltıp, ciro oranlarını düşüreceğinden, maliyetler azalacak ve tehlikeler daha az seviyeye inecektir. Çalışanların İSG'nin planlanması aşamasına katılması, pratik çözümlerin bulunmasına, bireysel önlemlerin alınmasına yardımcı olur. İSG sistemini şekillendirmede çalışanlara firsat verilirse ne şekilde etkili önlem alınacağına dair tavsiye ve önerilerde bulunup, bilgi verebilirler. Yatırımcılar, tüketiciler ve toplumlar arasındaki kurumsal sosyal sorumluluk için iyi bir itibardır. Çalışanların sağlıkları, mutlulukları ve motivasyonları artarak, üretimin artışı sağlanabilir (A Practical Guide, 2012: 11, 12).

İşbirliği yükümlülüğünün bir başka boyutunu da kurul çalışmalarına katılma oluşturmaktadır. İş Sağlığı ve Güvenliği Kurulları Hakkında Yönetmelik’te ${ }^{11}$ çalışanların kurula ilişkin genel yükümlülükleri düzenlenmiştir. Buna göre çalışanlar, sağlık ve güvenliğin korunması ve geliştirilmesi amacıyla İSG kurulları tarafından konulan kurallar, yasaklar ve alınan karar ve tedbirlere uymakla yükümlüdürler. Bu açıdan çalışanların aynı zamanda İSG kurulları ile işbirliği yapma yükümlülüğü de bulunmaktadır (Yön. md. 12/1, 2).

Her ne kadar çalışanların İSG kurulları ile işbirliği yapma ve kurul çalışmalarına katılma yükümlülüğü bulunmakta ise de bu yükümlülük her işyeri için söz konusu değildir. İşverenin İSG kurulu oluşturma yükümlülüğü, elli ve daha fazla çalışanın bulunduğu ve altı aydan fazla sürekli işlerin yapıldığı işyerlerinde için bulunmaktadır (6331 sayılı İSGK md. 22).

\section{iv) Çalışanların Bağımlıık Yapan Maddeleri Kullanma Yasağına İlişsin Yükümlülükleri}

İSG'ye ilişkin düzenlemelerin 4857 sayılı İK'da yer aldığı dönemde de alkol ve uyuşturucu madde kullanma yasağına ilişkin hüküm bulunmaktaydı. Ancak 6331 sayılı İSGK'nın yürürlüğe girmesi ve İK' da yer alan hükümlerin yürürlükten kalkması ile beraber işçinin bu konudaki yükümlülükleri yeniden düzenlenmiştir. 6331 sayılı İSGK'nın 28. maddesinde yer

${ }^{11}$ RG. 28532. 18.01.2013. 
alan düzenleme İK'da yer alan ve yürürlükten kalkan düzenleme ile paraleldir. Kanun metnine göre işçinin işyerine alkollü gelmesi değil sarhoş olarak gelmesi yasaklanmıştır. Ancak bazı durumlarda işçinin işyerine alkol almış olarak gelmiş olması sözleşmenin fesih nedeni olabilir. Yargıtay tarafından verilen eski tarihli bir kararda da "..Müşteri şikayetlerine ilişkin formlar ve açık kabulü karşısında davacının ara dinlenmesinde alkollü olarak işyerine geldiği, davacının alkollü olarak işyerinde bulunmasının müşteriler arasında rahatsızlık ve şikayetlere yol açtığı, davacının bu davranışlarının doğruluk ve bağlılığa uymadığı, şikayetlere yol açacak düzeyde alkol kokusu yayan davacının işyerine sarhoş olarak geldiğinin ve davalının iş akdini 4857 sayılı Kanun'un 25/11-d ve 84. maddeleri uyarınca haklı olarak feshettiğinin anlaşılması karşısında kıdem ve ihbar tazminatı taleplerinin reddi gerekirken hatalı değerlendirme ile yazılı şekilde karar verilmesi bozmayı gerektirmiştir." ifadesi kullanılmıştır. (http://ismahkemesi.com/2015/07/iscinin-isyerinde-alkol-almasiveya-ise-alkollu-gelmesi-yargitay-kararlari/: 2020) ${ }^{12}$. Yargıtay tarafından verilen başka bir kararda ise işyerine alkollü olarak gelmenin iş sözleşmesinin feshi için yeterli sayılmayacağ ifade edilmiştir. Alkollü içki içmiş olmakla beraber sarhoşluk belirtileri göstermeyen işçinin işyerine gelmesi İK'nın 25/2-d maddesince iş sözleşmesinin feshi için haklı neden olarak kabul edilmemiştir (http://al.av.tr/2017/01/17/yargitay-karari-iscinin-alkollu-ve-uyusturucumadde-kullanarak-ise-gelmesi/: 2020$)^{13}$. Esasen işyerinde alkol kullanımı konusu düzenlenmesi güç bir alanı oluşturmaktadır. Bu açıdan işçinin özel yaşamı ve işverenin işçiyi gözetme borcu karşı karşıya gelebilmektedir. Ancak işverenin alkol konusunda işyerinin özelliklerine uygun ölçütler getirebileceği kabul edilmelidir. Alkol ve uyuşturucu etkisi altında bulunulması ile iş kazası riskinin arttı̆̆ bilimsel bir gerçektir. Kanun koyucu işyerine alkollü olarak gelmek konusunda daha esnek bir yaklaşım sergilemiş olsa da uyuşturucu konusunda esneklik gösterilmemiştir. Hem işyerine uyuşturucu madde kullanmış olarak gelmek hem de işyerinde uyuşturucu kullanmak yasaklanmıştır (Özdemir, 2014: 453).

Sarhoşluğun tanımına ilişkin Kanunda herhangi bir düzenleme getirilmemiş olması uygulama açısından çeşitli sıkıntılara neden olabilecektir. İşçinin almış olduğu alkol miktarı iş sözleşmesinin feshedilmesinde haklı neden ya da geçerli neden tespitinde önemli olacaktır. Yargıtay'ın vermiş olduğu kararlar ışı̆̆ında alkol miktarının sözleşmenin fesih türünü belirlemede etkili olduğu sonucuna ulaşılmaktadır. Yüksek Mahkeme vermiş olduğu kararda "0.74 promil alkol seviyesi, iş sözleşmesinin feshinde haklı nedenle fesih sebebi ağırlığında değildir. Bu nedenle iş sözleşmesinin geçerli nedene dayanarak feshi gereklidir." ifadesi ile bu konudaki ayrıma vurgu yapmıştır (http://erdemozdemir-ishukuku. blogspot.com / 2013/10/is-sagligi-ve-guvenligi-bakimindan.html: 2013) ${ }^{14}$.

Bağımlılık yapan maddeler çerçevesinde işverenin işyerinde sigara içilmesine dair yasak koyup koyamayacağına ilişkin tartışmalar 4207 sayılı Tütün Ürünlerinin Zararlarının Önlenmesi ve Kontrolü Hakkında Kanun ${ }^{15}$ ile yapılan değişiklikle ortadan kalkmıştır. Kanun'un “Tütün Ürünlerinin Yasaklanması” başlıklı 2. maddesinde "Kamu hizmet binalarının kapalı alanlarında ve koridorları dahil olmak üzere her türlü eğitim, sağlık, üretim, ticaret, sosyal, kültürel, spor, eğlence ve benzeri amaçlı özel hukuk kişilerince ait olan ve birden çok kişinin girebileceği binaların kapalı alanlarında" tütün ürünlerinin tüketilemeyeceği belirtilmiştir.

Bazı ülkeler uzun zamandan beri işyerinde alkol ve uyuşturucu bağımlılığını önleme girişimlerini geliştirmek için sosyal taraflar ile bağımlılığın tarafları arasında etkileşim

\footnotetext{
${ }^{12}$ Yarg. 9. HD. 23.10.2013. E: 2011/33668. K: 2013/26777.

${ }^{13}$ Yarg. 9. HD. 8.12.2016. E: 2016/1000 E. K: 2016/21771.

${ }^{14}$ Yarg. 22. HD. 06.12.2011. E: 2011/3957. K: 2011/6839.

${ }^{15}$ RG. 22829. 26.11.1996.
} 
içerisindedirler. Ülkelerde işçilere, onların ailelerine, işverenlere alkol ve uyuşturucu bağımlılığını önlemenin yararları anlatılmaktadır. Ülke vatandaşları ve işverenler arasında işyerinde alkol ve uyuşturucu programlarına katılımcılık ve farkındalık önemli rol oynamaktadır. ILO, bu konuda giderek artan farkındalığı göz önüne alarak işyerinde alkol ve uyuşturucuya bağlı sorunların yönetimi ile ilgili sözleşmeyi 1995 yılında onaylamıştır (Prevention of Alcohol and Drugs Use in the Workplace, 2015).

657 sayılı DMK'da işyerinde alkol kullanmak ve işyerine sarhoş gelmenin yaptırımı düzenlenmiştir. Fiilin ağırlık derecesine göre göreve sarhoş gelmek ve görev yerinde alkollü içki içmenin yaptırımı, memurun kademe ilerlemesinin 1 ile 3 yıl arasında durdurulması olarak ifade edilmiştir (md. 125/D, a).

\section{IV- ÇALIŞANLARIN İŞ SAĞLIĞI VE GÜVENLİĞİ YÜKÜMLÜLÜKLERINI İHLALİN SONUÇLARI}

İş kazalarına yol açan sebeplerden en önemlisini insan hataları oluşturmaktadır. Bu sebebin yanında elbette çalışma ortamı, önlenemeyen nedenler gibi durumlar da bulunmaktadır. İnsan hatası, işçilerin işlerini görürken yapmış oldukları hatalardır. İşveren İSG'nin sağlanması amacıyla tüm yükümlülüklerini yerine getirse dahi çalışanlar tedbirlere yeterince özen göstermedikleri takdirde kaza ve hastalıklar kaçınılmazdır. Bu nedenle işverenlerin yanında çalışanların da birtakım yükümlülükleri bulunmaktadır (İren, 2006: 96). Çalışanlar özel hukuk veya statü hukuku çerçevesinde çalışabilecekleri gibi, işveren ile doğrudan veya dolaylı iş ilişkisi içinde de olabilirler. Çalışanın tabii olduğu mevzuata ve işverenle arasındaki iş ilişkisine bağlı olarak İSG yükümlülüklerinin ihlalinde farklı yaptırımlar uygulanmaktadır.

\section{A- İş Sözleşmesi ile Çalışanların Yükümlülüklerini İhlalin Sonuçları}

\section{1- Türk Borçlar Kanunu Kapsamında İşçinin Yükümlülüğünü İhlalin Sonuçları}

İşçinin özen borcu TBK'da düzenlenmiştir. İşçinin işini özenle yapma ve işverenin haklı menfaatini korumada sadakatle davranma yükümlülüğü bulunmaktadır (TBK md. 396/1). Aksi durumda işçinin işverene kusuru ile verdiği tüm zarardan sorumlu olacağ (TBK md.400). Aynı zamanda TBK' da işçinin İSG yükümlülüklerini yerine getirmediğinde iş sözleşmesinin işverence feshedilebileceği de düzenlenmiştir.

\section{i) İşçinin Kusuru ile Verdiği Zararın Tazmini}

TBK'nın 400. maddesinde işçinin sorumluluğu düzenlenmiş ve işverene kusuru ile verdiği tüm zarardan sorumlu olacağı belirtilmiştir. İşçi zararın meydana gelmesinde kusuru olmadığını ispat etmekle yükümlüdür. İşveren ise zarar ile işverenin davranışı arasındaki illiyet bağını ispat ile yükümlüdür (Eren, 2013: 543). Kanun koyucu 400. maddenin 2. fıkrasında işçinin sorumluluğunun belirlenmesinde göz önünde tutulması gereken kriterleri belirlemiştir. İşçinin sorumluluğunun belirlenmesinde işin tehlikeli olup olmaması, uzmanlık gerektirip gerektirmemesi ve işçinin işveren tarafından bilinen veya bilinmesi gereken yetenek ve nitelikleri göz önünde bulundurulacaktır. İşin tehlikeli olup olmaması ölçütü daha önce hukukumuzda yer almayan bir ölçüttür (Senyen Kaplan, 2014: 42, 43). İşçinin bilinen veya bilinmesi gereken nitelikleri bakımından; işveren işçinin kişisel ve mesleki durum ve düzeyini, eksikliklerini bilerek iş sözleşmesi yapmışsa, işçi bu durumu ileri sürerek kısmen veya tamamen sorumluluktan kurtulabilir (Eren, 2013: 1064). İşçinin Borçlar Kanunu'nun 146. maddesindeki sorumluluğu tazminat sorumluluğudur (Özdemir, 2014: 458)

TBK'da hizmet sözleşmesinden doğan herhangi bir borç nedeni ile önceden yapılacak sorumsuzluk anlaşmalarının her iki taraf açısından geçersiz olacağı belirtilmiştir (TBK md. 
115/2). Tarafların sorumluluğu belirlenirken açılacak tazminat davalarında işçinin sorumluluğu ve kusuru da göz önünde bulundurulmalıdır. Tazminatın belirlenmesi ile ilgili 51. maddede zarar ve tazminat belirlenirken işçinin kusurunun dikkate alınacağı ifade edilmiştir (Senyen Kaplan, 2014: 42). İSG önlemlerine uymayan işçi iş kazasına maruz kalırsa veya meslek hastalığına tutulursa müterafik kusuru işverenin tazminat sorumluluğunda da dikkate alınacaktır (İren, 2006: 95). 6331 sayılı İSGK' da "Çalışanların İSG konusundaki yükümlülükleri, işverenlerin sorumluluğunu etkilemez" hükmü yer alsa ve bu durum Çerçeve Yönergeye uygun dahi olsa buradan çıkarılması gereken sonuç, işverenin sorumluluğunu değil, yükümlülüklerini etkilemediği olmalıdır (Özdemir, 2014: 460).

\section{ii) Sözleşmenin Feshi}

TBK'da işçinin ISG yükümlülüklerini yerine getirmediğinde iş sözleşmesinin işverence feshedilebileceği düzenlenmiştir. Sözleşmenin derhal feshedilmesi hususunda; sözleşmeyi fesheden taraftan, dürüstlük kuralına göre hizmet ilişkisini sürdürmesi beklenemeyen bütün durum ve koşullar haklı sebep sayılacaktır (md. 435/2). İşçinin İSG yükümlülüklerini yerine getirmemesi, hizmet ilişkisinin devamının işveren tarafından sürdürülmesini beklenemez hale getirecek nitelikteyse, işveren işçinin iş sözleşmesini derhal feshedebilecektir.

İşçinin, işyerinde İSG açısından olumsuzluğa neden olan davranışları nedeniyle iş sözleşmesi feshedildiğinde, işverenin bu davranışı hâkim tarafından ölçülülük denetimine tabi tutulacaktır. İşçinin davranışının ortaya çıkardığ 1 olumsuzluğun ağırlığı karşısında haklı sebeple fesih en ağır disiplin yaptırımıdır. İşverenin fesih ile izlediği amaç, işçinin söz konusu davranışı bir daha tekrar etmesinin önüne geçmek olacağından, işverenin aynı amaca başka disiplin yaptırımları ile ulaşıp ulaşamayacağı denetim konusu yapılacaktır. İSG yükümlülüklerine aykırı davranan işçinin davranışı, doğrudan çalıştığı yer ile bağlantılı ise ve işçinin çalıştığı yer değiştirildiği takdirde sözleşmenin tekrar ihlal edilmesi rizikosu bertaraf edilecekse, işveren derhal fesihten önce bu seçeneğe başvurabilir (Ugan Çatalkaya, 2019: 492).

Kanunda haklı nedenle fesih dışında taraflardan her birinin, belirsiz süreli sözleşmeyi fesih sürelerine uyarak feshetme hakkı da düzenlenmiştir (md. 431/1). TBK'da, İK'da olduğu gibi iş sözleşmesinin geçerli nedenle feshi için belirli bir sebep gösterme zorunluluğu bulunmamaktadır. Yalnızca sözleşmelerin fesih hakkının kötüye kullanılarak sona ermesi halinde, işverenin işçiye "kötüniyet tazminatı" niteliğinde bir tazminat ödemesine ilişkin düzenleme bulunmaktadır (md. 434). İSG yükümlülüklerine aykırı davranan işçinin iş sözleşmesi TBK'da yer alan ve iş sözleşmesinin haklı nedenle feshedilmesini gerektirecek ağırlıkta değilse, işveren karşı tarafın hizmet süresine uygun bildirim süresi vererek iş sözleşmesini feshedebilecektir.

Süreli fesih hali için ölçülülük ilkesinin göz ardı edilmemesi gerekir. İşçinin davranışlarına dayanan feshin ölçülü sayılabilmesi için yalnızca işveren açısından elverişli ve daha hafif araçlara başvurma olanağının bulunmasına bakılmamalıdır. İşçinin davranışının, işverenin menfaatleri açısından katlanılamayacak bir yük getirmesi de aranmalıdır (Ugan Çatalkaya, 2019: 492, 493).

\section{2- İş Kanunu Kapsamında İşçinin Yükümlülüğünü İhlalin Sonuçları}

İşçi, işverenin hizmetinde onun çıkar ve menfaatlerini korumayı üstlenir. Bu borç sadakat borcudur. TBK'da işçiye yüklenen özen yükümlülüğü, sadakat borcunun gereğidir. 4857 sayılı İK'da işçinin özen borcuna ayrıca yer verilmemiştir. İşçinin özen borcu açısından TBK hükümleri dikkate alınacaktır (Özdemir, 2014: 453, 454). 
Çalışanların 6331 Sayılı Kanundan Doğan Yükümlülükleri ve Yükümlülükleri İhlalin Sonuçları

İşçinin İSG önlemlerine aykırı davranışı iş sözleşmesinin feshini gündeme getirebileceği gibi işçiye çeşitli disiplin cezası yaptırımları da uygulanabilecektir.

\section{i) İş Sözleşmesinin İşverence Haklı Nedenle Feshi}

İşçinin iş sözleşmesinden doğan asli edim yükümlüğü iş görme borcudur. İşçi, işin görülmesi sırasında işverenin emir ve talimatlarına uymakla yükümlüdür. İşçinin asli edim yükümlülüğünü ihlal etmesi hem tazminat sorumluluğunu gündeme getirir hem de İş Kanunu'nun 25/II maddesinde yer alan gerekçelerle iş sözleşmesi haklı nedenle feshedilebilir. İşveren, İSG bakımından işyeri düzenine ilişkin emir ve talimatlarda bulunabilir. Böyle bir durumda işçinin koruyucu ekipmanı kullanmamakta 1srar etmesi veya ISG eğitimlerine katılmaması gibi gerekçelere dayanarak işveren, görevlerini hatırlatıldığı halde yerine getirmeyen işçinin iş sözleşmesini haklı nedenle feshedebilir (25/II/h).

İşçinin özen borcuna aykırılık oluşturan işyerini tehlikeye sokan davranışları sonucunda herhangi bir zarar meydana gelmesi şart olmayıp, işyerini tehlikeye sokma ve zarar doğma ihtimalinin olması bile sözleşmenin feshi için yeterlidir (Özdemir, 2014: 462).

İş Kanunu'nun 25. maddesinin 1 bendinde işçinin özen borcunu ihlaline yönelik iki ayrı hal düzenlenmiştir. Bunlar işin güvenliğini tehlikeye düşürme ve işverene zarar vermedir. İşverenin almakla yükümlü olduğu İSG önlemlerine rağmen, işçinin tutum ve davranışlarıyla iş güvenliğini tehlikeye düşürmesi, çalışanlar yönünden zarar riski ortaya çıkarması sözleşmenin feshi için haklı bir nedendir. Düzenlemede haklı nedenin varlığı için iki koşul aranmıştır. Bunlar İSG önlemlerine kusurlu aykırılık ve bunun sonucunda iş güvenliğinin tehlikeye sokulmasıdır (Mollamahmutoğlu, Astarlı ve Baysal, 2013: 858). Kanundaki diğer özen borcuna aykırılığı işverene zarar verilmesi oluşturur.

Sadakat borcu oldukça geniş kapsamlı bir borçtur. İşçiye asli edim yükümlülüğü ve yan edim yükümlülükleri yükler. Borç, Medeni Hukukun iyi niyet kurallarının İş Hukukunda geniş bir şekilde uygulanmasını oluşturur. Hukukumuzda işverenin haklı nedenle derhal fesih sebepleri genellikle sadakat borcunu örnekler şekildedir. Sadakat borcunun ihlal edilmesi için işverenin zararının oluşması beklenmez. Sadakat yükümlülügüüü yerine getirmeme borcun ihlali için yeterlidir. İşçinin işini ifa ederken özen yükümlülügüunü ihmal etmesi sadakat borcunun ihlali sonucunu doğurur. Sadakat borcunun ihlali söz konusu olduğunda işverenin birlikte kusuru söz konusu olmaz. Bu açıdan borç işçiler için büyük önem arz etmektedir. Borcun ihlali işçinin iş sözleşmesinin haklı nedenle derhal feshini gerektirir (Mollamahmutoğlu, Astarlı ve Baysal, 2013: 601, 602).

Diğer taraftan işçinin bağımlılık yapan maddeleri kullanma yasağının ihlali de iş sözleşmesinin derhal feshi için haklı neden olarak düzenlenmiştir (25/II/d).

\section{ii) İş Sözleşmesinin İşverence Geçerli Nedenle Feshi}

İSG kapsamında işçinin yükümlülüklerini ihlali her zaman haklı sebeple fesih halini oluşturmayabilir. Fesih için geçerli bir neden varsa işveren iş sözleşmesini buna dayanarak feshedebilir. İşverene zarar verme ya da zararın tekrarı tedirginliğini yaratma, görevlerini (İSG kurallarına uyum) hatırlatıldığı halde eksik ve yetersiz yapma gibi işçinin yetersizliğinden veya davranışlarından doğan nedenler işyerinde olumsuzluklara yol açıyorsa geçerli fesih nedeni olarak görülebilir. Bu sebepler İK md. 25 ağırlığında olmasa bile, işin görülmesini önemli ölçüde etkileyen nedenlerdir. İşçinin davranışları işyerinin normal seyrini ve işyerindeki uyumu olumsuz yönde etkiliyorsa, işverenden iş ilişkisinin devamı beklenemiyorsa işverenin geçerli fesih hakkı doğar. İşçinin kusuru ile vermiş olduğu zarar otuz günlük ücreti tutarında değilse de işveren işçinin iş sözleşmesini geçerli nedenle feshedebilir (Senyen Kaplan, 2014: 46). 
İşçinin İSG'yi kusuru ile tehlikeye düşürmesi haklı nedenle fesih için yeterli olsa da işveren sözleşmeyi feshettikten sonra ispat sorunları ile karşılaşabilir. İşveren yükümlülüğe aykırılığın derecesine göre iş sözleşmesini geçerli nedenle feshedebileceği gibi farklı disiplin cezaları da uygulayabilir. Yargıtay bu yaptırımların belirlenmesinde özellikle haklı nedenle fesih ve geçerli nedenle fesih ayrımında ölçülülük ilkesini kullanmaktadır ${ }^{16}$. "Issçinin kendi isteği veya savsaması yüzünden işin güvenliğini tehlikeye düşürmesi, 25. maddenin 2 . fıkrasının 1 bendinin birinci cümlesi gereğince işverene haklı fesih hakkı verir. Güvenliği tehlikeye düşürme davranışın ağırlığı, görev tanımına, faaliyet alanına, görev yerine, işverenin gerekli önlemleri alıp almadığına, işçinin alınan önlemlere uyup uymadığına göre değişebileceğinden, nedeninin haklı veya geçerli neden teşkil edip etmediği, işverenin neden olup olmadığı ölçülülük ilkesince değerlendirilmelidir." (Özdemir, 2014: 466).

\section{iii) Disiplin Cezası}

İşverenlerin, işçilere yönelik disiplin cezası uygulama yetkisi vardır. Ancak iç hukukta cezanın kapsamı, sınırları, usulü, itiraz ve yargısal denetimine ilişkin genel hukukî düzenlemeler bulunmamaktadır. Hukukî düzenlemenin yapılmamış olması, işverene tanınan tek taraflı yetkinin kötüye kullanılması sonucunu doğurabilir. Toplu iş sözleşmeleri veya işyeri iç yönetmeliklerine konulacak hükümler ile sınırlı da olsa disiplin hukuku oluşturulabilir. İş hukukundaki disiplin cezaları; uyarı, kınama, ücret kesintisi, işin veya işyerinin değiştirilmesi, işten uzaklaştırma ve işten çıkarma şeklinde olabilir. Tüm bu yaptırımların uygulanması için hukukî dayanağın bulunması gerekir ve yaptırımlar kendi amaçlarıyla sınırlı olmalıdır. Somutlaştırmak gerekirse verilecek olan disiplin cezası işyeri düzeni ve disiplinini sağlamaya yönelik olmalıdır. Disiplin cezasının uygulanması için işçinin kusurlu olması gerekir ve disiplin cezasının verilebilmesi için disiplin cezalarını öngören hükümlerin bir üstte bulunan hukuk kaynağından daha ağır yaptırım içermemelidir. Ancak alttaki hukuk kaynağı daha hafif bir yaptırım öngörebilir. İş Kanunu'nda haklı sebeple derhal fesih hakkını doğuran bir olay, işyeri iç yönetmeliğinde veya toplu iş sözleşmesinde ücret kesintisi olarak kararlaştırılabilir (Süzek, 2011: 9-11).

İşyerinde oluşturulacak disiplin sistemi İSG açısından oldukça önemlidir. Bu sayede işveren işçiyi işten çıkarma yolundan önce davranışlarını düzeltmesi için ona başka yaptırım uygulayabilecek, işçi uyarıları dikkate almaması halinde işçiyi işten çıkarabilecektir (Özdemir, 2014: 481, 482).

\section{3- Alt İşveren İşçilerinin İş Sağlığı ve Güvenliği Yükümlülüklerini İhlalin Sonuçları}

Mevzuatta alt işveren işçilerinin İSG alanındaki yükümlülükleri ve yükümlülüklere aykırı davranmanın yaptırımı konusunda ayrı düzenleme bulunmamaktadır. Öğretide alt işveren işçilerinin, asıl işverenin işyerindeyken, asıl işverenin kendi işçileri ile aynı yükümlülüklere tabi olması yönünde bir hüküm bulunması gerektiği ifade edilmiştir (Sarıbay Öztürk, 2015: 50). Mevzuatta böyle bir hüküm bulunmasa dahi alt işveren işçilerinin çalıştıkları işyeri kendileri açısından ayrı bir işyeri sayılacağından asıl işveren işçileri İSG'yi sağlama noktasında hangi yükümlülükler altındaysa alt işveren işçileri de bu yükümlülüklere uymak zorundadirlar.

Alt işveren işçilerinin İSG'ye ilişkin yükümlülüklere uymamasından dolayı asıl işverenin yaptırım uygulayıp uygulayamayacağı ise öğretide tartışmalıdır. Asıl işverenin, alt işveren işçilerine disiplin cezası uygulayamayacağını savunan görüş; disiplin cezası verme yetkisinin işverenin iş sözleşmesinden doğan yönetim hakkından kaynaklandığııı, asıl işveren arasında sözleşmesel bir bağ bulunmayan alt işveren işçilerine karşı disiplin cezası

${ }^{16}$ Yarg. 9. HD. 03.05.2010. E: 2009/20255. K: 2010/11968. 
uygulayamayacağını belirtirken (Süzek, 2011: 12) diğer görüşe göre disiplin cezası verilmesinin nedeni işyerinde bozulan düzeni sağlamak olduğu için alt işveren işçileri asıl işverenin işyerindeki çalışma düzenini ihlal ediyorsa, asıl işveren tarafından toplu iş sözleşmesi veya işyeri iç yönetmeliğinde düzenlenmiş olmak kaydıyla alt işveren işçilerine disiplin cezası uygulayabilmelidir (Başbuğ, 1999: 193). Assl işveren ile alt işverenin işçileri arasında sözleşmesel bir ilişki bulunmadığından ve alt işverenin işçilerinden asıl işveren ve alt işverenin müteselsil sorumluluğunun sınırlı olarak var olmasından ötürü bu görüşe katılmak mümkün görünmemektedir. Yargıtay 9. HD. tarafindan 30.09.2015 tarihinde verilen 2015/21179 esas, 2015/26948 karar sayılı kararda ifade edildiği üzere, alt işveren işçilerine disiplin cezası uygulama yetkisinin asıl işverende bulunması muvazaa olarak değerlendirilmektedir (Yıldız, 2019: 214).

Disiplin cezası dışında İSG yükümlülüklerine aykırı davranan işçilerin iş sözleşmeleri alt işveren tarafından geçerli veya haklı nedenle feshedilebilecektir. Burada uygulanacak yaptırımın belirlenmesinde ise ölçülülük ilkesi dikkate alınacaktır. Yargıtay tarafından da ifade edildiği şekilde ${ }^{17}$ "Güvenliği tehlikeye düşürme davranışının ağırlığı, görev tanımına, faaliyet alanına, görev yerine, işverenin gerekli önlemleri alıp almadığına, işçinin alınan önlemlere uyup uymadığına göre değişebileceğinden, nedeninin haklı veya geçerli neden teşkil edip etmediği, işverenin neden olup olmadığı ölçülülük ilkesi kapsamında değerlendirilmelidir." (Yıldız, 2019: 216).

\section{4- Geçici İşçilerin İş Sağlığı ve Güvenliği Yükümlülüklerini İhlalin Sonuçları}

İş ilişkisinin geçici olarak kurulması işverenlerin gözetme borcunu ortadan kaldırmayacağı gibi İSG konusunda önlem alma yükümlülüğünü de ortadan kaldırmayacaktır (İren, 2011: 281). Geçici iş ilişkisinde alt işverenlik ilişkisinden farklı olarak dikkat edilmesi gereken; alt işveren iş aldığı ve kendisi açısından ayrı bir işyeri anlamını taşıyan bölümde işveren sıfatı ile tam bir yönetim ve organizasyon hakkına sahipken, geçici iş ilişkisinde yönetim ve organizasyon hakkı geçici işçinin işvereni sıfatını taşımamasına rağmen iş görme ediminin alacaklısı olan geçici işverendedir (Süzek, 2019: 290). Geçici işçi sıfatı ile başka işverene ait işyerinde iş görmekteyken İSG yükümlülüklerine aykırı davranan işçiye uygulanacak yaptırımlarda geçici işverenin söz hakkı olup olmadığg gündeme gelecektir.

Geçici işçiyle geçici işveren arasında kurulan ilişki, iş ilişkisi benzeri bir ilişkidir. Dolayısıyla taraflar arasında iş sözleşmesi kurulmuş denilemeyecektir. Ancak geçici iş ilişkisinde işin görülmesini isteme hakkı geçici işverene geçeceğinden işin görülmesi ile ilgili yönetim yetkisi ve emir ve talimat verme yetkisi artık geçici işverendedir. (İK md. 7/9) Talimatlar yalnızca işin görülmesini isteme ile sınırlı olarak düşünülmemelidir. İşveren işyeri düzeninin sağlanması ve güvenliğin sağlanmasına yönelik iş̧̧inin davranışlarına ilişkin birtakım talimatlarda da bulunabilir (Süzek, 2019: 299).

Geçici işveren işyerinde çalışan işçilere yönelik hiçbir ayrım yapmamak suretiyle İSG Kanunu ve bu Kanuna dayanarak çıkarılan yönetmelikleri uygulamakla yükümlüdür. Geçici işveren ile geçici işçi arasında iş sözleşmesi kurulmadığından işveren, İSG yükümlülüklerine uygun davranmayan işçilerin iş sözleşmelerini feshedemeyecektir.

Geçici işçilerin çalışma ortamında sağlık ve güvenliğinin sağlanması önemli bir konudur, bu konuda 6331 sayılı İSGK'ya dayanılarak Geçici veya Belirli Süreli İşlerde İş Sağlığı ve Güvenliği Hakkında Yönetmelik ${ }^{18}$ çıkarılmıştır. Yönetmeliğin çıkış noktasını esasen 91/383/EC sayılı ve 25 Haziran 1991 tarihli AB Direktifi oluşturmaktadır. Yönetmeliğin 3.

\footnotetext{
${ }^{17}$ Yarg. 9. HD. 23.12.2015. E: 2015/24759. K: 2015/36525.

${ }^{18}$ RG. 28744. 23.08.2012.
} 
maddesinde düzenlemenin AB Konsey Direktifine paralel olarak hazırlandığ ifade edilmiştir (md. 3) (Erdoğan, 2017: 136).

Öğretide Direktif ve Yönetmeliğe yönelik çeşitli eleştirilerde bulunulmuştur. Gerek İSG konusundaki eğitim yükümlülüğü gerekse bilgilendirme yükümlülüğü gibi yükümlülüklerin bordro işvereni ve geçici işveren arasında hassas şekilde dağıtılmaması ve iki düzenlemede bu konuya ilişkin yeterince açık düzenleme bulunmaması, tarafların sorumluluklarının Direktifte yeterince açık belirtilmemesi eleştirilerden bazılarıdır. Geçici işçilere uygulanacak İSG hükümlerinin ana çerçevesinin Kanun olması ve tarafların sorumluluklarının doğrudan İSGK ile belirlenmesi gerektiği belirtilmiştir (Özdemir, 2014: 395, 396).

Geçici işçiler ile daimi işçiler arasında İSG hususu bakımından eşitlik vardır. Yönetmeliğin 5. maddesinde bu durum açıkça düzenlenmiştir. Geçici işverenin, geçici işçiye emir ve talimat verme yetkisi 4857 sayılı Kanunda açıkça düzenlenmişse de (md.7/1) geçici işverenle işçi arasında sözleşmesel ilişki bulunmadığından ISG önlemlerine aykırı davranan işçinin iş sözleşmesini feshedemeyecektir. Ancak yükümlülüğe aykırı davranması halinde geçici işçi ile arasında kurulan sözleşme benzeri hukuki ilişkiyi sona erdirebilme hakkına sahip olmalıdır. İşveren, sahip olduğu emir ve talimat verme yetkisiyle geçici işçiye disiplin cezaları da uygulayabilecektir.

\section{5- Devlet Memurları ve 657 sayılı DMK Kapsamında Diğer Çalışanların İş Sağlığı ve Güvenliği Yükümlülüklerini İhlalin Sonuçları}

6331 sayılı İSGK ve bu Kanun kapsamında çıkarılmış Yönetmelikler kamu sektörüne ait tüm işlere, işyerlerine ve bu işyerlerinin tüm çalışanlarına faaliyet konularına bakılmaksızın uygulanır (md. 2). Türkiye'de kamu çalışanları açısından İSG kültürünün yeterince gelişmemiş olması bu alandaki sorunların artarak devam etmesine neden olmaktadır. Ayrıca bürokratik problemler, İSG için ayrılacak bütçe sorunu, idarecilerin konuyu yeterince önemsememesi ve ISG'yi yeterince ciddiye almamasi ISGK'da yer alan pek çok yükümlülüğün yerine getirilmemesine neden olmaktadır (Demir ve Demir, 2016: 190). Kamuya ait birimlerde İSG hizmetlerinin yerine getirilmesinde sorumlu olan kişi idari amirdir. Ancak görev tanımı gereği ilgili birimde personelden sorumlu olan üst yönetim de gerekli çalışmaları yapmak, yapılan çalışmaları izlemekle sorumludur. Üst yönetim İSG'ni sağlamak amaciyla İSG profesyonelleri görevlendirmek, görevlendirilen kişilere çalışma ortamı sağlamak, işbirliği ve koordinasyonu sağlamak, İSG alanında önlemler almak, çalışanları bilgilendirmek ve iş kazası ve meslek hastalıklarını bildirmekle görevlidir. Çalışanlar bu kapsamda alınan önlemlere uymakla yükümlüdür (ÇSGB: 2015).

Memurlar ile işçilerin tek bir Kanuna bağlanmasının isabetli olmadığ görüşünü doğuran alanlardan birini iki grup arasındaki yaptırım farklılıkları oluşturmaktadır. Aynı işyerinde değişik statülerde istihdam edilenler aynı yükümlülükler ile yükümlü kılınırken, yükümlülüklerin ihlali durumunda da aynı yaptırımların uygulanması gerekliydi. İK kapsamındakiler için söz konusu olan fesih yaptırımı memurlar için söz konusu değildir, yaptırımlar arasında eşitsizlik bulunmaktadır. 657 sayılı DMK'da yer alan yaptırımlar çalışanların sağlık ve güvenliğinden ziyade devletin araç ve gereçlerinin korunması ön planda tuttuğu için eleştiri konusu olmuştur (Özdemir, 2014: 482, 483).

\section{i) Uyarma ve Kınama Yaptırımı}

657 sayılı DMK'ya göre memurlara uygulanacak yaptırımlar beş başlık altında toplanmıştır. $\mathrm{Bu}$ yaptırımlardan ikisi uyarma ve kınama yaptırımlarıdır. Uyarma; memura görevinde, davranışlarında daha dikkatli olması gerektiğinin yazı ile bildirilmesi olarak tanımlanmıştır. Yaptırımın gündeme gelmesini gerektiren fiiller 657 sayılı Kanunda sayılmıştır. Bu fiillerin 
İSG ile ilgili hükümleri “...verilen emir ve görevlerin tam zamanında yapılmasında görev mahallinde kurumlarca belirlenen usul ve esasların yerine getirilmesinde, görevle ilgili araç ve gereçlerin korunması, kullanılması ve bakımında kayıtsızlık göstermek veya düzensiz davranmak..." olarak gösterilebilir. İşyerinde İSG ile ilgili araçların kullanımına kayıtsız kalan, bu konuda düzensiz davranan kimselere uyarma yaptırımı uygulanabilecektir. Aynı bent kınama yaptırımı içinde ele alınmıştır. Kınama; memura görevinde ve davranışlarında kusurlu olduğunun yazı ile bildirilmesidir. $\mathrm{Bu}$ bent dışında kınama yaptırımının nedenlerinden bir diğeri “...verilen emirlere itiraz etmek”tir. İSG'yi sağlamaya yönelik verilecek emirlere itiraz eden memur hakkında bu yaptırım uygulanabilecektir.

Memurların İSG'yi tehlikeye düşürecek davranışlarından doğabilecek muhtemel zarar üçüncü kişilere yönelik değil kendisine yönelikse bile, haklarında disiplin cezası uygulanabilecektir (İnciroğlu, 2017).

\section{ii) Kademe İlerlemesinin Durdurulması Yaptırımı}

Çalışanların İSG'yi sağlamaya yönelik yükümlülüklerinden birinin işyerinde alkol kullanmamak veya işyerine sarhoş olarak gelmemek olduğundan bahsedilmişti. 657 sayılı DMK kapsamında göreve sarhoş gelmek, görev yerinde alkollü içki içmenin yaptırımı kademe ilerlemesinin durdurulmasıdır.

\section{iii) Kamu Personelinin Tazminat Sorumluluğu}

ISG mevzuatının idare tarafından uygulanması konusunda görevlendirilen kişilerin kusurlarından dolayı idarenin sorumluluğunu doğuran hizmet kusuru gündeme gelir. 657 sayılı Kanun'un 4/A bendinde yer alan memurlar, 4/B bendinde yer alan sözleşmeli personel ve 4/C bendinde yer alan geçici personel ile 4/D bendinde tanımlanan işçilerin idare tarafından yürütülen İSG faaliyetlerinde görev almaları halinde sorumluluğun kime ait olacağının belirlenmesi gerekir. Anayasa'nın 129. maddesinde memurların ve diğer kamu görevlilerinin yetkilerini kullanırken kusurlarıyla verdikleri zararlardan kaynaklanan tazminat davalarının doğrudan idare aleyhine açılması gerektiği belirtilmiştir. Tam yargı davası neticesinde tazminat ödemek zorunda kalacak olan idarenin, kusuruyla ISG'ye aykırı faaliyetlerde bulunan memur ve diğer kamu görevlilerine borçlar hukuku ilke ve kurallarına göre rücu hakkı saklıdır (Baycık, 2013: 159, 160).

\section{iv) Sözleşmeli Personelin Hizmet Sözleşmesinin Feshedilmesi}

Sözleşmeli Personel Çalıştırılmasına İlişkin Esaslar hakkında Bakanlar Kurulu tarafından 16330 sayılı Resmi Gazete'de çıkarılan Kararda, 657 sayılı DMK'nın 4. maddesinin (B) fikrası hükmüne sözleşme ile çalıştırılan ve işçi sayılmayan kamu hizmeti görevlileri de İSGK kapsamına alınmıştır. Bu kapsamda çalışanların İSG'nin sağlanması noktasında birtakım yükümlülükleri bulunmaktadır. Sözleşmeli Personel Çalıştırılmasına İlişkin Esaslar çerçevesinde sözleşmede yazılı olan görev veya iş dışında çalıştırılan personelin geçirdiği iş kazasından idareci sorumlu olsa da sözleşmeli personelin, hizmet sözleşmesinin esaslarına aykırı hareket etmesi halinde sözleşmeleri tazminatsız feshedilebilecektir. Ayrıca kamu işvereni tarafından sözleşmelerinde bulunan diğer disiplin hükümleri de uygulanabilecektir (İnciroğlu, 2017).

\section{v) Geçici Personel Hakkında Uygulanacak Yaptırım}

“Özelleştirme Uygulamaları Sonucunda İşsiz Kalan ve Bilahare Kalacak Olan İşçilerin Diğer Kamu Kurum ve Kuruluşlarında Geçici Personel Statüsünde İstihdam Edilmelerine İlişkin Esaslar" doğrultusunda işlediği suç ve fiillerden ötürü çeşitli Kanun, tüzük ve yönetmeliklerde devlet memurları için suç sayılan fiil ve hareketlerle yaptırımlar geçici 
personeller için de geçerlidir. Bu statüde çalışanlar sözleşmede yer alan şartlara uymadıkları takdirde Kurum tarafından sözleşmenin feshedilmesi veya yenilenmemesi halinde iş sonu tazminatı alamayacaklardır. İSG açısından yükümlülüklerine uymayan geçici personeller hakkında memurlara uygulanacak yaptırımlar gündeme gelebilecek, bu kimseler hakkında disiplin işlemleri uygulanabilecektir (İnciroğlu, 2017).

\section{SONUÇ}

Avrupa Birliği İş Sağlığı ve Güvenliği Müktesebatına uyum süreci içerisinde hazırlanmış olan 6331 sayılı ISSGK'da çalışan kavramı 89-391 sayılı direktife uygun olarak düzenlenmiştir, çalışan tanımı yapılırken ekonomik faaliyet ayrımına gidilmemiştir. Ancak bazı mesleki faaliyetler Kanun kapsamı dışarısında bırakılmıştır. Kanunda çalışanların İSG alanındaki yükümlülükleri ayrıca ele alınmıştır. Kanun'un 19. maddesinde çalışanların yükümlülükleri, işyerindeki makine, araç, gereç, cihaz, tehlikeli madde, taşıma ekipmanı ve diğer üretim araçlarını doğru kullanma, çalışanlara sağlanan kişisel koruyucu donanımları doğru kullanma ve koruma, işyerinde sağlık ve güvenlik yönünde ciddi ve yakın bir tehlike ile karşılaşıldığında durumu işveren veya çalışan temsilcisine haber verme ve işyerinde ISG alanındaki eksikliklerin giderilmesi ile ilgili işveren ve çalışan temsilcisi ile işbirliği yapma olarak belirtilmiştir. Çalışanların yükümlülükleri işveren tarafından verilen eğitim ve talimatlar doğrultusundaki yükümlülüklerdir. Ayrıca Kanun'un 28. maddesinde çalışanların işyerinde bağımlılık yapan madde kullanmalarına ilişkin düzenleme yer almaktadır. $\mathrm{Bu}$ hükümde hangi işyerlerinde alkollü içki yasağının uygulanmayacağı da belirtilmiştir. Hükümde çalışanların işyerine alkollü gelmesi değil sarhoş olarak gelmesi yasaklanmıştır. İşyerinde alkollü içki veya uyuşturucu madde kullanmak Kanunda yasaklanmıştır.

İş sağlı̆̆ı ve güvenliğini sağlamak için çalışanlar tarafından uyulması gereken yükümlülüklerin ihlali bazı yaptırımların uygulanmasına neden olacaktır. Bu yaptırımlar çalışanların statüsüne bağlı olarak değişiklik gösterebilecektir. Çalışanın İSG'yi sağlama borcu yalnızca İSGK kapsamında düzenlenmiş bir borç değildir. TBK'da işçilerin işini özenle yerine getirme borcu, işyerindeki araç ve gereçleri koruma borcu düzenlenmiştir. Bu borçlara aykırılığın yaptırımı zararların tazmin edilmesidir. Tazminatın hesaplanmasında işçinin kusuru kadar işverenin ISG alanındaki yükümlülüklerini yerine getirip getirmediği de incelenecektir. İşveren tarafından verilmesi gereken eğitimlerin verilmemesi sonucu işçinin bilgisizliğinden veya eğitimsizliğinden dolayı İSG ihlal edilmiş ve ortaya bir zarar çıkmışsa yalnızca işçinin sorumluluğu gündeme gelmeyecektir. Tazminat yaptırımdan başka işçinin iş sözleşmesi haklı sebeple derhal veya bildirim süresi verilerek feshedilebilecektir. İK kapsamında ise işçinin yükümlülügünü ihlal etmesi sadakat borcuna aykırı davranıştır. İK'nın 25. maddesinde işveren tarafindan iş sözleşmesinin haklı nedenle derhal fesih nedenleri düzenlenmiştir. İşçinin 30 günlük ücreti ile karşılanamayan zarara neden olması halinde iş sözleşmesi haklı nedenle derhal feshedilebilecektir. Ayrıca işveren tarafından alınmış önlemlere uyulmaması herhangi bir zarar meydana getirmemiş olsa dahi iş sözleşmesinin haklı nedenle feshi sonucu doğabilir. Haklı nedenle fesih dışında işveren iş̧̧inin sözleşmesini geçerli nedenle de feshedebilecektir. Haklı nedenle fesih ve geçerli nedenle fesih arasındaki ayrım hâkim tarafından ölçülülük ilkesi gözetilerek yapılacaktır. Fesih dışında iş hukuku kapsamında işverenlere tanınan bir diğer yetki disiplin cezası verme yetkisidir. Yaptırımların uygulanması için geçerli hukukî dayanaklarının bulunması ve yaptırımların kendi amaçları ile sınırlı olması gerekir. Alınan İSG önlemlerine uyulmaması halinde uyarı, kınama, ücret kesintisi, işin ve işyerinin değiştirilmesi gibi disiplin cezaları verilebilir.

6331 sayılı İSGK kapsam ve faaliyetler bakımından istisnalar hariç sektör ayırt etmeksizin tüm çalışanlar açısından uygulama alanı bulacağından İSG yükümlülükleri 657 sayılı DMK 
kapsamında çalışanlar için de geçerlidir. 657 sayılı DMK'ya tabi olarak çalışan kimselerin İSG yükümlülüklerini ihlal etmeleri halinde birtakım yaptırımlar gündeme gelecektir. $\mathrm{Bu}$ kapsamda çalışan kişilere uygulanacak olan yaptırımlar 657 sayılı DMK'nın İSG ile ilgili hükümleri göz önüne alınarak belirlenecektir. 657 sayılı Kanunda yer alan ve İSG'nin sağlanmasına yönelik hükümler, çalışanların sağlık ve güvenliğini sağlamaktan ziyade devletin araç ve gereçlerini koruma odaklı olduğu ileri sürülerek eleştirilmiştir. 657 sayılı Kanun kapsamında çalışanlar hakkında İSG ile ilgili verilen emir ve görevlerin yapılmasında ve İSG'nin sağlanması açısından kullanılacak araçların kullanılması ve bakımı konusunda kayıtsız kalınması halinde uyarma ve kınama yaptırımları gündeme gelebilecektir. Kanunda işyerinde alkol kullanmanın ve işyerine sarhoş gelmenin yaptırımı ise kademe ilerlemesin durdurulması olarak düzenlenmiştir. $\mathrm{Bu}$ yaptırımlar dişında kamu çalışanları, ISSG faaliyetlerini yerine getirirken ve kamu görevinden doğan yetkilerini kullanırken kusuru ile verdikleri zarardan sorumludurlar. 657 sayılı DMK kapsamında çalışan sözleşmeli personeller İSG yükümlülüklerini ihlal ettikleri takdirde işveren tarafından sözleşmeleri tazminatsız feshedilebilecektir. Sözleşmenin tazminatsız feshi dışında kendileri hakkında birtakım disiplin cezaları da uygulanabilecektir. Sözleşmeli personellerde olduğu gibi geçici personeller de İSG yükümlülüklerine aykırı davrandıkları takdirde sözleşmeleri feshedilebilecek veya yenilenmeyebilecektir. Ayrıca geçici personeller hakkında, memurlar için geçerli olan diğer yaptırımlar da uygulama alanı bulabilecektir.

\section{Kaynakça}

Alpagut, G. (2014). 6331 Sayılı İş Sağlı̆̆ ve Güvenliği Kanunu'nun Genel Esasları, Prof. Dr. Berrin Ergin'e Armağan. İstanbul Üniversitesi Hukuk Fakültesi Mecmuası, Cilt: LXXII. Sayı: 2. İstanbul: Legal Yayınc1lık. 31-45.

Atan, M., Cam, E., Çelik, E., Yazar A., Berna ve Boz Eravcı, D. (2017) Türkiye'de İş Sağlığı ve Güvenliği Algısı Araştırma Raporu. Çalışma ve Sosyal Güvenlik Eğitim ve Araştırma Merkezi. Yayın No: 58. Ankara.

Balkır, Z. G. (2012a). İş Sağlığı ve Güvenliği Hakkının Korunması: İşverenin İş Sağlığı ve Güvenliği Organizasyonu. Sosyal Güvenlik Dergis. 2 (1). 56-91.

Balkır, Z. G. (2012b). 6331 Sayılı İş Sağlığı ve Güvenliği Kanunu'nda İşverenin İş Sağlığı ve Güvenliği Yönetim Sorumluluğu. Sicil.28. 2042.

Baloğlu, C. (2013). Avrupa Birliği ve Türkiye'de $\dot{I}_{S}$ Sağllğ $\imath$ ve Güvenliği. 1. Bası. İstanbul: Beta.

Baloğlu, C. (2015). Çalışanların İş Sağlı̆̆ı ve Güvenliği Yükümlülükleri ve Aykırılığın İş İlişkisine Etkisi. Kamu-IŞ İs Hukuku ve Iktisat Dergisi. 14 (1). 17-28.

Başbuğ, A. (1999). Türk İş Hukukunda Disiplin Cezaları. Ankara: Tes İş.

Baycık, G. (2013). Çalışanların İş Sağlığı ve Güvenliğine İlişkin Haklarında Yeni Düzenlemeler. Ankara Barosu Dergisi. 2013 (3). 105-170.
Çatalkaya Ugan, D. (2019). İ̧s Hukukunda Ölçülülük İlkesi. İstanbul: Beta.

Çelik, N., Caniklioğlu, N. ve Canbolat, T. (2019). İş Hukuku. Yenilenmiş 32. Bas1. İstanbul: Beta.

Demir, B. ve Demir, N. (2016). Kamu Sektöründe 6331 Sayılı İş Sağlığı ve Güvenliği Yasasının Uygulanması ve Mevcut Yükümlülükler. İstanbul Aydin Üniversitesi Dergisi. Say1: 29. 167-194.

Eren, F. (2013). Borçlar Hukuku, Genel Hükümler. 15. Bas1. Ankara: Yetkin.

Erdoğan, C. (2017). Geçici İş İlişkisinde İşverenin İş Sağlığı ve Güvenliği Önlemleri Alma Yükümlülüğü. YBHD. 2017 (2).

Erol, S. (2015). İş Sağlığı ve Güvenliği Konusunda İşveren, Çalışan ve Devletin Rolü. ASSAM. 2 (4). 115-137.

Gerek, N. (2013). İş Sağllğı ve Güvenliği Kanunu'nun Düşündürdükleri. Sicil. 28. 10-20.

İnciroğlu, L. (2017). Çalışanların İş Sağlı̆̆ı ve Hükümlerine Aykırı Davranışının Hukuki Sonuçları. www.inciroğludanismanlik.com (Erişim: 24 Kasım 2020).

İnciroğlu, L. (2008). Işş̧i Sağlı̆̆ ve $\dot{I}_{S}$ Güvenliğinde İş̧i ve İşverenin Hukuki ve Cezai Sorumluluklart. İstanbul: Legal. 
İren, E. (2011). Geçici İș İlişsisinde İșverenlerin İş Sağlığı ve Güvenliği Önlemleri Alma Yükümlülüğü. AÜHFD 60 (2). 281-307.

İren, E. (2006). İşçilerin İş Sağlığ 1 ve Güvenliği Kurallarına Uyma Yükümlülüğü ve İhlali Halinde Karşılaşacakları Müeyyideler. Sicil. 3. 92-103.

Kabakçı, M. (2009). İş Sağlığı ve Güvenliğinin Hukuk Sistemindeki Yeri. TBB Dergisi. 86. 249267.

Kılıç, L. (2006). İşverenin İş Sağlĭğ ve Güvenliğini Sağlama Hükümlülüğ̈̈ ve Sorumluluğu. Ankara: Yetkin.

Kurt, R. (2013). Herkes Iç̧in İş Sağll̆ğ ve Güvenliği Rehberi. Ankara: Seçkin.

Mollamahmutoğlu, H., Astarlı, M. ve Baysal, U. (2014). Işs Hukuku. Gözden Geçirilmiş 6. Bası. Ankara: Turhan.

Özdemir, E. (2014). İş Să̆ll̆̆g ve Güvenliği Hukuku. İstanbul: Vedat.

Öztürk Sarıbay, G. (2015). ișs Sağlı̆̆l ve Güvenliği Yükümlülüklerinin Yerine Getirilmemesinin Hukuki, İdari ve Cezai Sonuçları. İstanbul: Beta.

Senyen/Kaplan, E. T. (2014). 6331 Sayılı İş Sağlığ1 ve Güvenliği Kanunu'nda Çalışanların Yükümlülükleri. Sicil. 31. 37-49.

Süzek, S. (2005). İşçilerin İş Sağlığ 1 ve Güvenliği Konusundaki Hakları ve Yükümlülükleri, Legal İş Hukuku ve Sosyal Güvenlik Hukuku Dergisi. Say1: 6. 609-622.

Süzek, S. (2006). İşverenlerin İş Sağliğ 1 ve Güvenliği Konusundaki Yükümlülükleri. $\dot{I} S S S_{S}$ Hukuku ve Sosyal Güvenlik Hukuku Türk Milli Komitesi 30. Yıl Armağanı. 507-528.

Süzek, S. (2011). İş Hukukunda Disiplin Cezaları. Çalışma ve Toplum Dergisi. Sayı:28. (9-11).

Süzek, S. (2019). İ̧̧ Hukuku. 17. Bası, İstanbul: Beta.

Yağız, Ç. (2011). 6098 Sayılı Türk Borçlar Kanunu'na Göre Hizmet Sözleşmesinin 393-413 Maddeleri Işı̆̆ında ve 818 Sayılı Borçlar Kanunu ile Kiyaslanarak İncelenmesi. Legal Işs Hukuku ve Sosyal Güvenlik Hukuku Dergisi. Cilt 8 (30). 517-547.

Yıldız, E. (2019). Asıl İşveren Alt İşveren İlişkisinde $\dot{I}_{S ̧}$ Să̆llğg ve Güvenliği Yükümlülükleri. İstanbul Üniversitesi Sosyal Bilimler Enstitüsü: Yayınlanmamış Yüksek Lisans Tezi.
Yılmaz, M. (2013). Kamu Kurumlarında İş Sağlığg ve Güvenliği Kanunu'nun Uygulanması. ÇSGB Çalışma Dünyası Dergisi. 1 (2). 39-51.

Yiğit, A. (2013). Işs Güvenliği. 2. Bası. Bursa: Dora.

Workers' Participation [http:// www . ilo . org / legacy/english/osh/en/story_content/external_fil es / fs_st_4 - worker_3_en.pdf ]. (Erişim: 26 Kasim 2020).

OSHA [https://osha.europa.eu/en/about-eu-osha /what-we-do]. (Erişim: 26 Kasım 2020)

A Practical Guide. Worker Participation in Occupational Safety ve Health A Practical Guide (2012). [https:// osha . europa . eu / en / publications/worker-participation-occupationalsafety-and-health-practical-guide]. (Erişim: 26 Kasim 2020).

[http:// ismahkemesi . com / 2015 / 07 / iscininisyerinde - alkol - almasi - veya - ise - alkollugelmesi-yargitay-kararlari/]. (Erişim: 24 Kasım 2020).

[http:// al . av . tr / 2017 / 01 / 17 / yargitay-karari - iscinin - alkollu - ve - uyusturucu - maddekullanarak-ise-gelmesi/: 2020]. (Erişim: 26 Kasim 2020).

[http:// erdemozdemir - ishukuku . blogspot . com / 2013 / 10 / is - sagligi - ve - guvenligi bakimindan.html]. (Erişim: 07 Eylül 2020).

Prevention of Alcohol and Drugs Use in the Workplace. [http:// www . ilo . org / safework / areasofwork / workplace-health-promotion-andwell - being / WCMS _ 108398 / lang -en/index.htm]. (Erişim: 26 Kasım 2020)

İstanbul Tabip Odası. İşçi Sağlığı ve İş Güvenliği Kanun Tasarısı Kabul Edilemez, [http://iyh.istabip.org.tr/index.php?option=com _content\&view=article\&id=226:isci-sagligi-veis-guvenligi-kanun-tasarisi-kabul-edilemez]. (Erişim: 20 Ekim 2015)

[https://www.sabah.com.tr/yasam/2014/05/15/d emirleri - isirarak - oksijen - aldik?paging $=6$ ] (Erişim: 26 Kasım 2020).

ÇSGB (2015). Kamuda İş Sağlığı ve Güvenliği. Ankara. [https:// aybu . edu . tr / isg / contents / files / Kamuda\%20\%C4\%B0\%C5\%9F\%20Sa \%C4\%9Fl\%C4\%B1\%C4\%9F\%C4\%B1\%20ve \%20G\%C3\%BCvenli\%C4\%9Fi.pdf]. (Erişim: 23 Kasım 2020). 